\title{
Review \\ Correlation between Flotation and Rheology of Fine Particle Suspensions
}

\author{
Mohsin Sajjad ${ }^{1}$ and Akira Otsuki ${ }^{1,2, *}$ \\ 1 Ecole Nationale Supérieure de Géologie, GeoRessources UMR 7359 CNRS, University of Lorraine, \\ 2 Rue du Doyen Marcel Roubault, BP 10162, 54505 Vandœuvre-lès-Nancy, France; \\ mohsin.sajjad@hotmail.com \\ 2 Waste Science \& Technology, Luleå University of Technology, SE 97187 Luleå, Sweden \\ * Correspondence: akira.otsuki@univ-lorraine.fr
}

check for updates

Citation: Sajjad, M.; Otsuki, A. Correlation between Flotation and Rheology of Fine Particle Suspensions. Metals 2022, 12, 270 . https://doi.org/10.3390/ met12020270

Academic Editors: Antoni Roca and Felix A. Lopez

Received: 16 December 2021

Accepted: 25 January 2022

Published: 1 February 2022

Publisher's Note: MDPI stays neutral with regard to jurisdictional claims in published maps and institutional affiliations.

Copyright: (C) 2022 by the authors. Licensee MDPI, Basel, Switzerland. This article is an open access article distributed under the terms and conditions of the Creative Commons Attribution (CC BY) license (https:// creativecommons.org/licenses/by/ $4.0 /)$.

\begin{abstract}
This paper summarizes and discusses previous investigations into the correlation between the rheology and flotation process of fine particle suspensions. This summary provides a better understanding of the challenges and current status of this subject and useful feedback based on the revision of relevant theories and practical implications for fine particle characterization and processing. Such processes include the sustainable beneficiation of complex ores and wastes for valuable material extraction and the segregation of toxic substances. For example, there has been increasing demand for the beneficiation of complex ores often carrying the values (e.g., critical raw materials) in fine grains, due to the noticeable decrease in the accessibility of high-grade and easily extractable ores. To maintain the sustainable use of limited resources, the effective beneficiation of complex ores is urgently required. It can be successfully achieved only with selective particle/mineral dispersion/liberation and the assistance of mineralogical and fine particle characterization including a proper understanding of the rheological behavior of complex ores in the context of fine particle separation/processing. In correlating flotation with suspension rheology, previous works were summarized and we found that the modeling of their correlations as well as comprehensive contributions of pulp and froth rheology on flotation performance have been studied very limitedly, and comprehensive developments in these aspects are thus strongly suggested.
\end{abstract}

Keywords: complex ore; gangue; zeta potential; Derjaguin-Landau-Verwey-Overbeek theory; pulp rheology; froth rheology; bubble size; critical raw materials

\section{Introduction}

Mineral and metal extraction industries play an important role in the current global economy. Mineral processing is one of the key areas among such industries in order to achieve and maintain sustainable use of natural resources. Flotation, in mineral processing, is a vital method to separate and concentrate valuable minerals from non-valuable ones (gangues) by using the contrast in their surface hydrophobicity/hydrophilicity [1,2] that can be altered by the addition of chemical reagent(s). According to Somasundaran et al. (2007), a billion tons of ores are treated by the flotation process annually, and about 95\% of the base metals produced are beneficiated through this process [3].

Economically, important metal and mineral raw materials are deemed "critical" when their risk of supply shortage is high [4]. This definition implies that the criticality of a raw material is determined by geopolitics (e.g., distance to material source and accessibility through trading agreements) and that it can change over time (e.g., due to changes in market demand).

In a report published by the European Union (EU), a total of 83 individual raw materials were assessed and the overall results of the 2020 criticality assessment are presented in Figure 1 [5]. Critical raw materials (CRMs) are highlighted by red dots and are located 
within the criticality zone (SR $\geq 1$ and $E I \geq 2.8$ ) in Figure 1 . Supply Risk (SR) was calculated based on factors that measure the risk of disruptions in supply of a given material (e.g., supply concentration, import reliance, governance performance measured by the World Governance Indicators, trade restrictions and agreements, existence, and the criticality of substitutes), while Economic Importance (EI) was calculated based on the importance of a given material in the EU for end-use applications and in the performance of its substitutes in these applications [5]. Blue dots represent the non-critical raw materials.

The easy-to-access CRMs have been exhausted, thus leading to a situation where the remaining ores are of lower grade and more complex (e.g., complex carbonate-rich mixed Cu-Co ore [6], refractory gold ore [7]). Apart from having low-grade primary ore deposits, Europe also possesses large amounts of metals which are locked up in industrial process residues, such as tailings, metallurgical sludges, slags, dust, and ashes [8-11] that often exist in the form of fine grains/particles. Therefore, it is important to efficiently and effectively beneficiate complex ores/residues that often carry valuable minerals/materials in fine grains/particles.

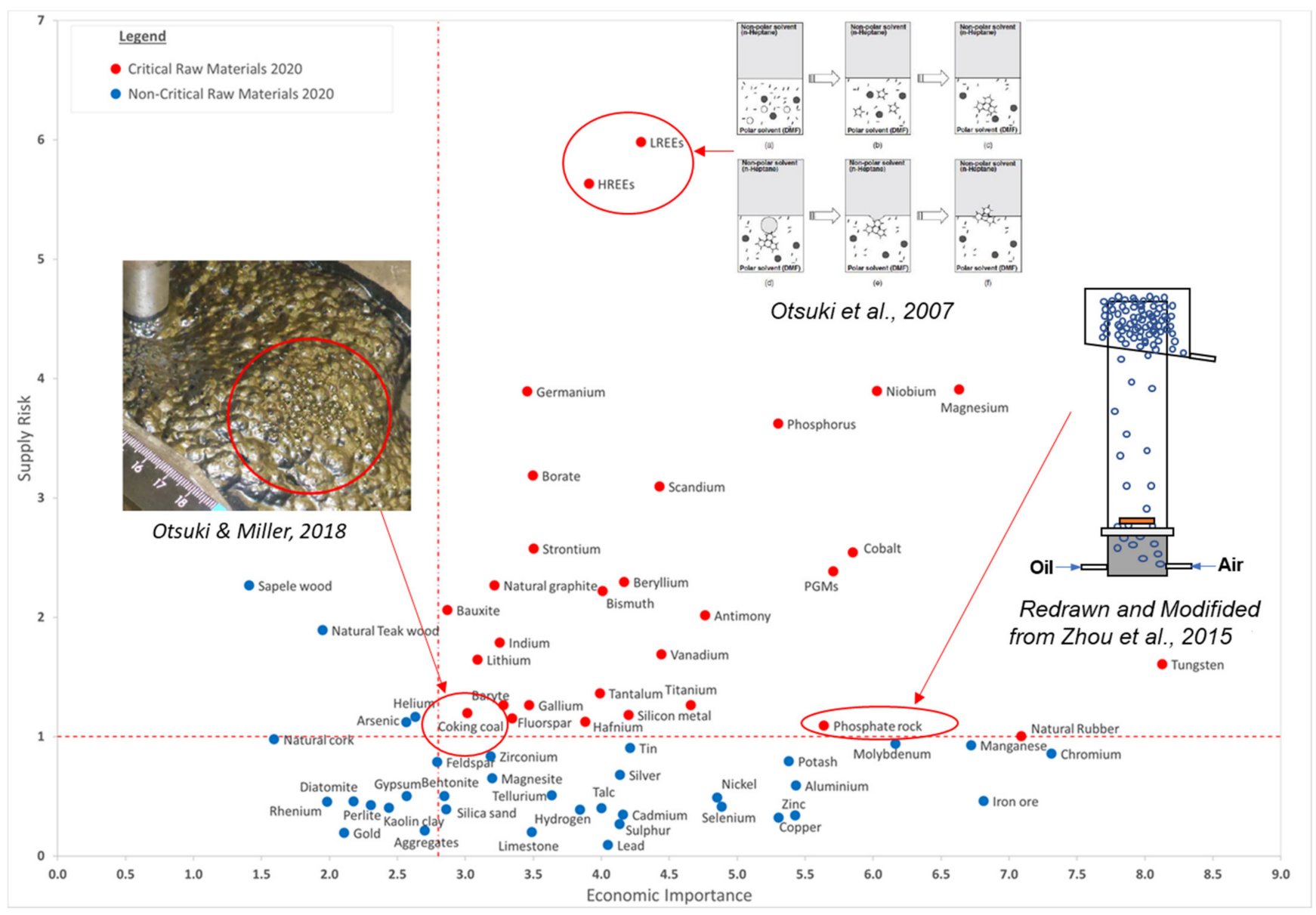

Figure 1. Economic importance (EI) and supply risk (SR) results of 2020 criticality assessment, reprinted with permission from [5]. Copyright 2020 European Commission, together with previous reports on flotation application to recover some CRMs adapted from [12-14].

Fluorescent powders are widely used in the manufacturing of luminescent materials, such as three-band fluorescent lamps [15]. These powders contain rare earth elements (REEs) that are considered risk elements since most of them are imported from only a few countries [16-18]. Otsuki et al. (2007) [12] studied the heterocoagulation of microsize particles and non-polar oil droplets in a polar organic solvent in order to verify the mechanism of two-liquid flotation (TLF) when separating ultrafine particles. Two-liquid 
flotation, also referred to as liquid-liquid extraction, is a mineral processing method for separating a mixture of ultra-fine particles (less than $10 \mu \mathrm{m}$ ) [19,20] by using two solvents with different polarities, i.e., polar and non-polar solvents, in order to create two different phases and use their interface for separation. They also reported a set of experimental results regarding the separation of a mixture of fluorescent powders by TLF [21,22]. They used various fluorescent powders, i.e., red $(2.6 \mu \mathrm{m})$, green $(1.1 \mu \mathrm{m})$, and blue $(2.1 \mu \mathrm{m})$. In their first step, the green powder migrates toward a non-polar phase (n-heptane) and remains at the interface of two solvents; however, the remaining two components precipitate in the polar phase (N, N dimethylformamide (DMF)). In their second step, the blue powder migrates toward non-polar phase, and remains at the interface of two solvents, whereas the red powder precipitates in the polar phase. The grade and recovery of each product after the two steps of TLF were between $90 \%$ and $95 \%$, respectively.

Magnesium (Mg) carbonates (salt-type minerals) are typical gangue phases associated with several valuable minerals, such as phosphates (e.g., apatite), sulfates (e.g., barite), halides (e.g., fluorite), tungstates (e.g., scheelite) [23], sulfides [24], and other oxides [25]. The separation of apatite (a valuable mineral of phosphate ores) from gangue minerals such as dolomite and quartz is one of the most critical steps in phosphate processing. The presence of slimes (fine gangue mineral particles) is one of the essential challenges during flotation in the presence of $\mathrm{Mg}$ carbonate [26]. The low hardness of carbonates leads to slime problems. Carbonate slimes can cover the surfaces of their associated valuable minerals, change their surface properties, and make their flotation complicated [27-29]. Therefore, it is highly recommended to reject the $\mathrm{Mg}$ carbonates prior to the processing of other minerals. Zhou et al. (2015) [13] performed micro-flotation to selectively float and recover single mineral particles of apatite $\left[\mathrm{Ca}_{5}\left(\mathrm{PO}_{4}\right)_{3}(\mathrm{~F}, \mathrm{Cl}, \mathrm{OH})\right]$ from dolomite $[(\mathrm{Ca}$, $\left.\mathrm{Mg})\left(\mathrm{CO}_{3}\right)_{2}\right]$ and quartz $\left[\mathrm{SiO}_{2}\right]$ (between 45 and $75 \mu \mathrm{m}$ ) using their reactive oily bubble technology. Using conventional air bubbles in the presence of a collector (fatty acids), the contact angles of apatite and dolomite were $72.5^{\circ}$ and $67.0^{\circ}$, respectively. On the other hand, when oily bubbles were used instead of conventional air bubbles, the contact angles for apatite and dolomite were reported as $83.0^{\circ}$ and $5.7^{\circ}$, respectively.

Coal is still the world's largest source of electricity and will still contribute $22 \%$ in 2040. This number is even higher in emerging markets in South East Asia, where coal will fuel 39\% of electricity in 2040 [30]. Otsuki and Miller (2018) [14] investigated a safer frother for coal flotation with achieving similar or better flotation performance, compared with the most common frother, methyl isobutyl carbinol (MIBC), which has caused some fire hazards in the past due to its low flash point (F.P. $=39^{\circ} \mathrm{C}$ ). Once the coal is mined, it can be classified into four size categories: coarse $(+10 \mathrm{~mm})$, intermediate $(1-10 \mathrm{~mm})$, fine $(150 \mu \mathrm{m}-1 \mathrm{~mm})$ and ultrafine $(-150 \mu \mathrm{m})$ particles [31]. To separate the coal from gangue minerals, processes using the density difference between the coal and the gangue are used for the separation of larger/coarser particles while froth flotation is used for the fine and ultrafine particles of the above categories. They found that Pine oil (F.P. $=78^{\circ} \mathrm{C}$ ) achieved high coal grade $(91-92 \%)$ and recovery $(76 \%)$, similar to the results with MIBC, while Dow Froth 250 (F.P. $=149^{\circ} \mathrm{C}$ ) achieved the highest grade $(96 \%)$ but low mass recovery $(30 \%)$.

It is known that flotation of minerals/particles by a conventional mechanical flotation cell is typically applicable for a particle size range from 10 to $100 \mu \mathrm{m}$ [32]. Floatable particle size range can also be varied with mineral type/density, and the maximum size can be extended to $500 \mu \mathrm{m}[14,33,34]$. Figure 2 shows typical flotation recoveries as a function of particle size and time for different minerals (i.e., quartz, chalcopyrite, and galena) by mechanical flotation cells [34]. These curves present the maximum recovery at around $100 \mu \mathrm{m}$ and a decrease in the recovery of finer or coarser size particles attributed to low particle-bubble collision probability or high detachment probability, respectively $[34,35]$. 


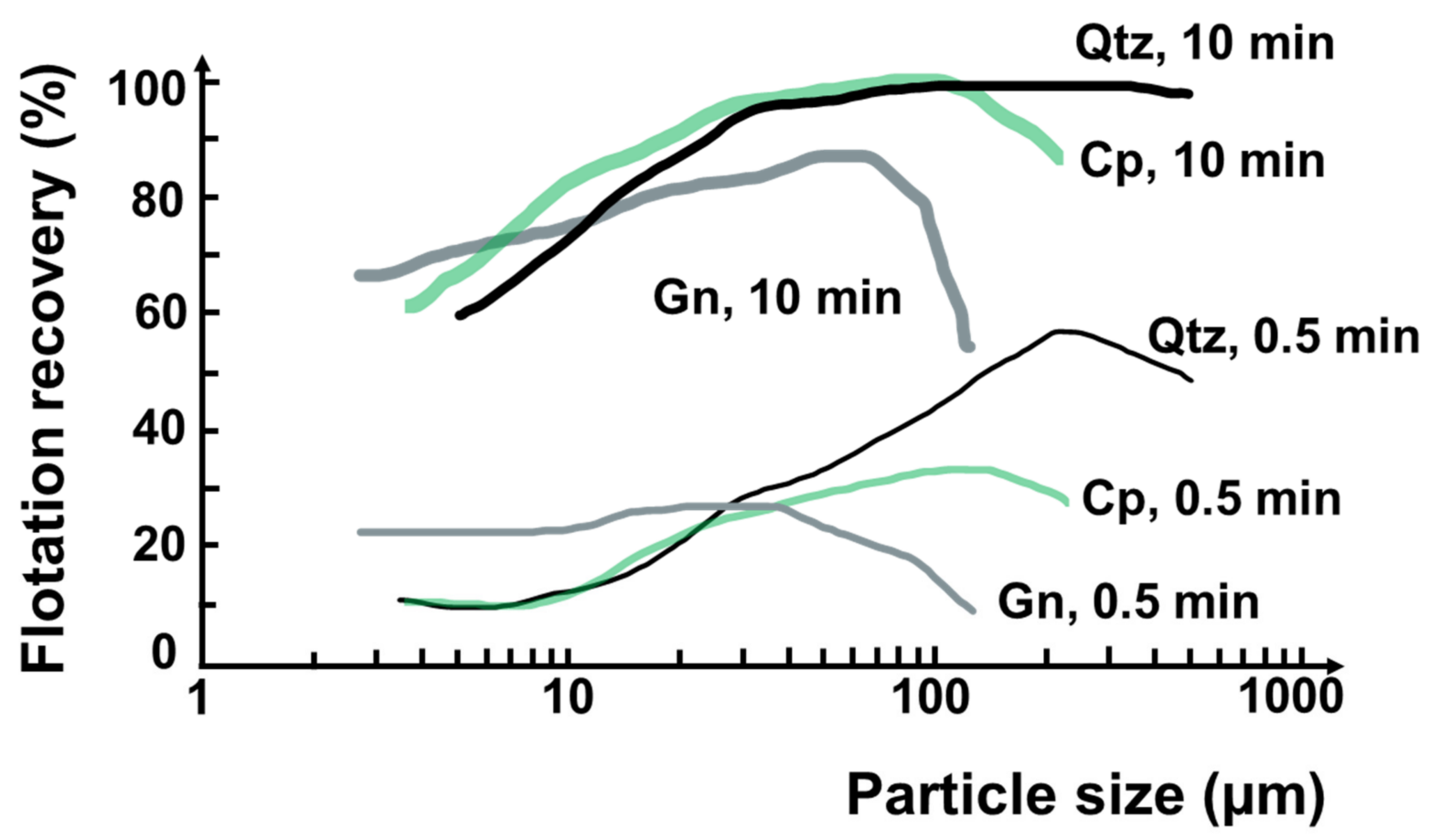

Figure 2. Flotation recovery of different mineral particles at 0.5 and $10 \mathrm{~min}$. Qtz, Cp and Gn refer to quartz, chalcopyrite, and galena, respectively. Redrawn and adapted from [34].

This flotation recovery trend is common to all mechanical flotation machines, independent of their size and the types of minerals floated. The particle size of maximum recovery may slightly increase for lighter minerals (e.g., $200 \mu \mathrm{m}$ with quartz) or decrease for denser minerals (e.g., 30-50 $\mu \mathrm{m}$ with galena) [34,36]. On the other hand, the particles below $10 \mu \mathrm{m}$ are considered very difficult to recover selectively due to their very low collision probability with bubbles [37-40], and entrainment [37,41,42]. The key parameters in fine particle flotation include bubble size [43,44], particle aggregation [45], and flow conditions [35].

Ahmed and Jameson (1985) [43] reported that the flotation rate constant of fine particles $(<50 \mu \mathrm{m})$ increased up to five hundred-fold $\left(1 \times 10^{-4} \mathrm{~s}^{-1}\right.$ to $5 \times 10^{-2} \mathrm{~s}^{-1}$ at $\left.300 \mathrm{rpm}\right)$ when the bubble size was reduced from $655 \mu \mathrm{m}$ to $75 \mu \mathrm{m}$. Hu et al. (2003) [45] studied the effect of particle aggregation and the flotation behavior of hematite and wolframite. They found that in turbulent flow conditions, a larger floc can be formed due to the adhesion of fine particles (less than $5 \mu \mathrm{m}$ ) onto a coarse particle surface, and some middle-sized flocs formed by fine particle aggregation themselves reached to the reasonable particle size of flotation up to $30 \mu \mathrm{m}$. An increase in agitation speed enhances the collision rate between fine and coarse particles, and it also increases the collector chemisorption on the mineral surface. This effect in return enhances the flotation recovery of fine particles [45].

It is known that the rheological behavior of mineral slurries affects their processing [46]. In addition to controlling the transportation of slurries around processing circuits [47], rheological behavior may also influence process operations, including grinding [48-51], classification [52-55], and flotation [56,57]. The impact of rheology on those unit operations has received considerable attention; however, studies on the correlation between rheology and flotation are still limited.

Shi and Zheng, 2003 [58] discussed the importance of the froth rheology and employed a modified rheometer in an industrial-scale flotation experiment. They found that froth rheograms showed a non-Newtonian behavior (pseudoplastic flow) and suggested to use the local or apparent viscosity which varies with the shear rate, in the calculations of froth mobility and stability. 
Jeldres et al., 2019 [59] reviewed the negative effects caused by different clay minerals in the flotation of copper ores. They found that in the presence of fine clay minerals, their pulps tend to behave as a non-Newtonian fluid, and properties such as viscosity and yield stress begin to have a dominant role in the hydrodynamics of the system, causing the decrease in the collision rates between bubbles and particles and thus a decrease in the recovery and grade of valuable minerals. They also reported that there is a direct relationship between the pulp viscosity and froth stability. Subrahmanyam and Forssberg [60] reported that a too stable froth may increase the froth viscosity due to the presence of fine particles. It also reduces the froth drainage effectiveness for selective rejection of the gangue particles back to the pulp and therefore increases the water recovery and particle entrainment against the true/ideal selective flotation.

Cruz et al., 2019 [61] reviewed slurry rheology in mineral processing unit operations (e.g., grinding, classification, flotation, dewatering, and tailings management). They emphasized the importance of the correlation of yield stress with the DLVO (DerjaguinLandau-Verwey-Overbeek) forces in most slurries made of nearly spherical colloidal particles with homogenous surface charges; however, in the presence of clay minerals non-DLVO forces also present and the rheological behavior becomes much more difficult to predict. Wang and Li, 2020 [62] reviewed pulp and froth rheology and found that due to the complex nature of various flotation feeds no general agreement has been reached in the correlation between flotation performance (i.e., recovery and grade) and the rheological behaviors of flotation pulps and froths.

While these previous literature reviews provide valid discussion within limited and specific points of their interest (e.g., issues with clay/fine particle presence), overarching discussion in terms of rheology-flotation correlation and their challenges is very limited as far as the authors' best of knowledge.

Studying rheology in flotation systems and their correlation can help us better understand the limitation in fine particle flotation and provide better feedback to improve its performance. Within this framework, in this article, we report our thorough literature review and summarize the challenges in fine particle flotation, the rheology of fine particle suspensions, and their correlation. Please note that our review focuses on the correlation between the flotation and rheology of fine particle suspensions, and thus their individual components (i.e., flotation-Section 2, rheology-Section 3) are also summarized from this point of view. Review articles focusing on their individual components can also be found within our review, and thus readers interested in those components can also seek additional information there. A summary and future perspectives will also be provided at the end of this review article. Thus, this article will provide possible and specific future research directions in this important and useful correlation based on the research gaps identified here.

\section{Flotation}

Flotation is a process that selectively separates materials based on their degree of hydrophobicity (water repelling property) using air/gas bubbles [63-65]. In 1905 (Broken Hill, Australia), the first attempt to apply a froth flotation apparatus was recorded, with the intense stirring of the pulp and injection of air bubbles [66]. Most of the early developments in flotation processing originated in Australia between 1900 and 1910. No metallurgical process developed in the 20th century competes the froth flotation, which has had a profound effect on the mineral industry [3].

Figure 3 shows (a) the principle of a mechanical froth flotation process as well as (b) physico-chemical properties of fine particles and their behaviors. In this unit operation, the ground ore is mixed with water to form a slurry and the surfaces of the target minerals are usually rendered more hydrophobic by the addition and adsorption of surfactant(s), called the collector in mineral processing, although some mineral surfaces (e.g., freshly ground sulphides, coal $[65,67])$ are naturally hydrophobic, requiring little or no addition of surfactants. The selection of surfactants is made depending upon the nature of the 
valuable mineral and the unwanted minerals, i.e., gangue [68]. The slurry (pulp) of the mixture of hydrophobic and hydrophilic particles is introduced to tanks known as flotation cells, where air bubbles are produced. As mechanical cells are the main machines used in industry and studies of correlation between rheology and flotation of fine particles, we focused on the mechanical cells in this literature review.

The hydrophobic particles attach onto the air bubbles rising to the surface of the pulp, forming a three-phase zone, so-called froth, on the top of the flotation cell. The froth is made of air bubbles, solids, and water [65], and is recovered as a concentrate of the target mineral, in the case of direct flotation [69]. This concentrate can be sent to further metallurgical processes to produce pure metals [70,71]. On the other hand, the non-valuable minerals stay in the flotation cell as tailings.

As an alternative to agitated cells, bubble columns-used in chemical engineering practice as chemical reactors-were proposed for the treatment of fine particle systems. Flotation columns, as they came to be known, were "invented" back in the $1960 \mathrm{~s}$ in Canada. Agitation is generally achieved by the inflow of air and/or slurry, and air bubbles are usually introduced by an injector [72]. The main feature that differentiates the column from the mechanical flotation cell (of Denver type) is the longer residence time, leading to the higher particle-bubble collision probability enhancing fine particle recovery. Another feature is wash water, added at the top of the froth. It is beneficial to overall column performance, since it helps clean the froth from any entrained gangue, while at the same time preventing water from the pulp flowing into the concentrate. Based on these features, it is often installed in cleaning stages of flotation circuit [73].

The Jameson flotation cell is widely known to be efficient at fine coal recovery [74]. The Jameson Cell is a high efficiency flotation separator, which uses induced air from atmosphere. Air is induced into the downcomer through the influence of the jet action produced by the pressurized pulp. Compared with conventional flotation machines, the Jameson Cell features high-efficiency cleaning, excellent separation performance, simple circuits, and low operating cost. Although the structure of the Jameson Cell is simple, there are some parameters in its design based on the differences in mineral floatability and working environment [75-77]. The main parameters include the shape and height of the nozzle above the pulp level. By changing the shape of nozzle or increasing the energy of the jet velocity created by the slurry passing through the nozzle, the size of bubbles decreases, both the number of bubbles and dynamic turbulence intensity in separation tank increases leading to increase in bubble-particle collision and thus in the high flotation efficiency [78-81].

Reactor-separators (RS) are the modern generation of flotation machines. Each reactorseparator consists of an aerator, a reactor, and a separator. In the top part of the reactor, air is automatically injected from the atmosphere in an initial feed at a pressure on the order of $0.2-0.3 \mathrm{MPa}$. As mineral particles or drops of emulsion move along the reactor, they attach to air bubbles. After the bubbles enter the separator, they ascend and are removed together with the foam product. The residue (the cleaned solution) is removed through the bottom of the separator chamber [82]. The flotation sub-processes in an RS differ from the processes that take place in other types of flotation machines (impeller- and column-type machines). In an RS, flotation proceeds in two successive stages: first the particles attach to the bubbles in the reactor; then the mineralized bubbles are removed from the pulp in the separator. In all other types of flotation machines, the mineralization of the bubbles and their removal from the pulp take place simultaneously [68]. 


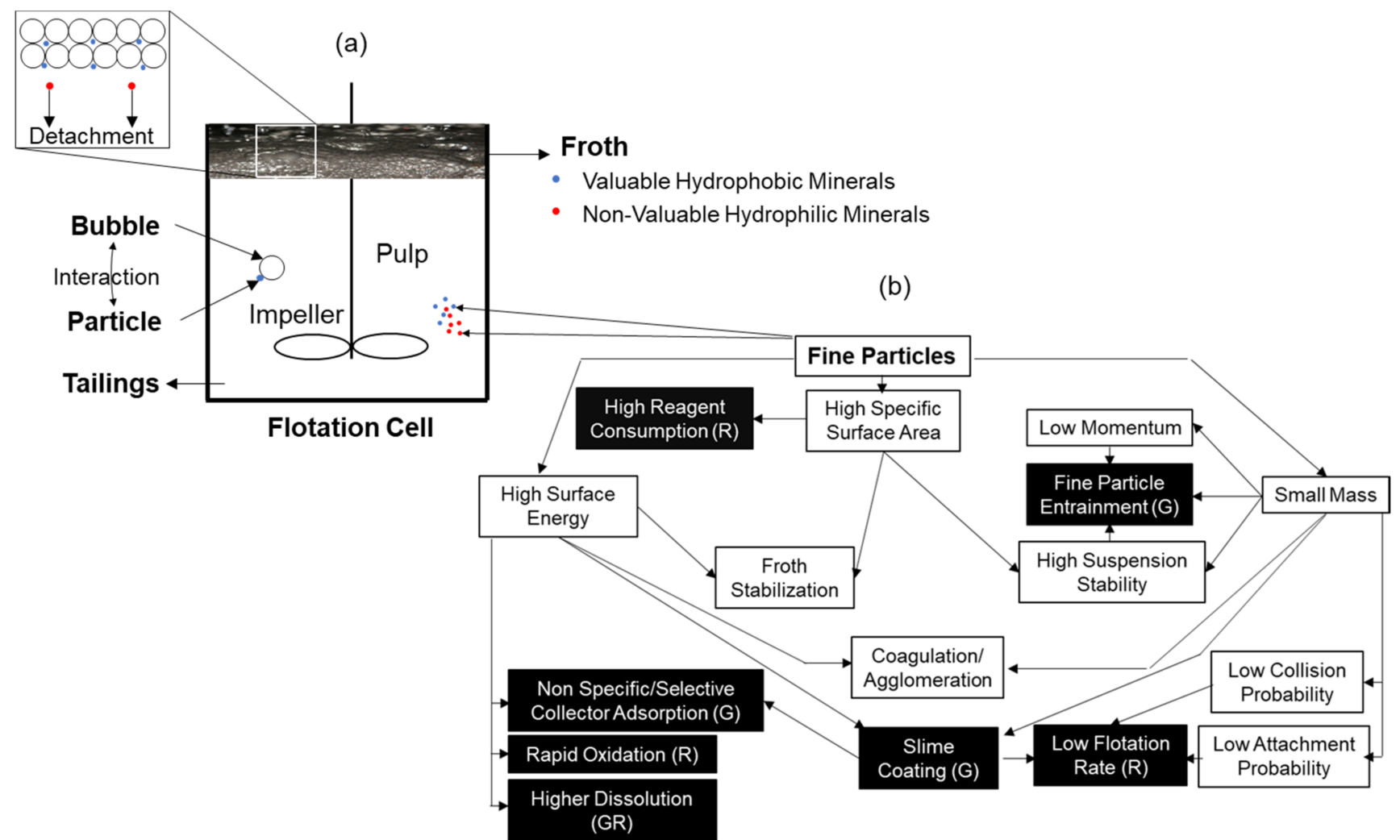

Figure 3. (a) Schematic explaining the principle of a mechanical froth flotation process. (b) Schematic diagram showing the relationship between physical and chemical properties of fine particles and their behaviors in flotation; $(G)$ and $(R)$ refer to whether the phenomenon affects the grade or recovery, individually or both together. The highlighted (black) cells indicate the possible drawbacks of the presence of fine particles on flotation performance. Redrawn and adapted from [83]. Used with permission of The Minerals, Metals \& Materials Society.

Specific surface area, which is the surface area per unit volume or weight, is inversely proportional to particle size. As the particles become smaller, the ratio of edges, corners, cracks, and dislocations of particle surface increases, which results in high surface energy of particles. Several factors, such as non-selective adsorption of reagents, fast surface oxidation in the case of sulfides, increased hydration, and solubility of complex minerals, are claimed to be the consequences of the high surface energy of fine particles. This results in poor flotation performance, in terms of recovery and grade adapted from [84].

During the crushing and grinding processes, because of the generation of sharp edges and imperfections of particle surfaces, the solubility of fine particles in water is significantly enhanced [85]. The increased solubility would introduce undesired impurities in the flotation system, leading to the increased concentration of ionic components, therefore, unavoidably affecting interactions between valuable minerals and collectors. For example, dissolved metallic ions may activate gangue minerals, making flotation separation more difficult [86]. This again results in poor flotation performance, in terms of recovery and grade.

Figure 4 shows particle size and associated flow regimes, as well as forces and parameters influencing flotation performance. Three kinds of force coexist to various degrees in flowing suspensions: hydrodynamic, Brownian, and colloidal forces. Hydrodynamic (or viscous) forces arise from the relative motion of particles to the surrounding fluid and exist in all flowing suspensions. Brownian force is the ever-present thermal randomizing force that ensures particles undergo constant translational and rotational movements. Colloidal forces are potential forces and are elastic in nature $[87,88]$. The relative magnitude of these 
forces, and thus the bulk rheology depends on the particle size of a suspension. Brownian motion and interparticle colloidal forces can be competitive for sub-micrometer-sized $\left(d_{\mathrm{p}}<10^{-3} \mu \mathrm{m}\right)$ suspensions, while hydrodynamic forces dominate for particles larger than approximately $10 \mu \mathrm{m}$. For particles in the intermediate range $\left(10^{-3} \mu \mathrm{m}<d_{\mathrm{p}}<10 \mu \mathrm{m}\right)$, their flow behavior is determined by a combination of hydrodynamic forces, Brownian motion, and interparticle colloidal forces [89,90].
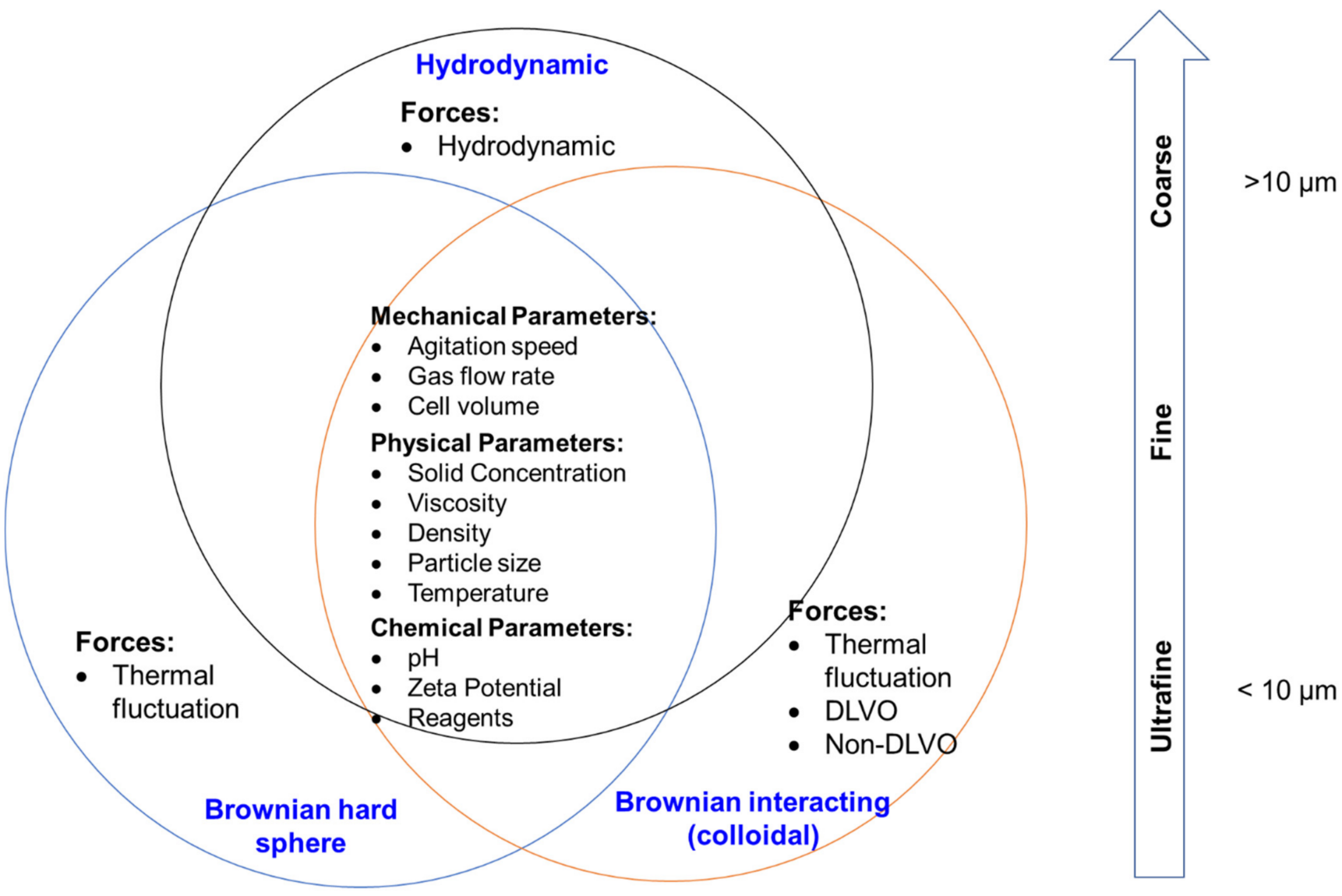

Particle Size

Figure 4. Particle size ranges and their associated flow regimes, forces, and parameters influencing flotation performance.

Hard spheres are inert, rigid, and monomodal spherical particles [89]. In the flow behavior of their suspensions, interparticle forces are negligible against hydrodynamic forces and Brownian diffusion. Metzner [91] also suggested that when the viscosity of the continuous phase is very high (more than about $100 \mathrm{~Pa}$ ), interparticle forces could be negligibly small compared to viscous force. Hard spheres are classified as Brownian or non-Brownian, depending on their size [88]. The flow of suspensions of non-Brownian hard spheres is totally dominated by hydrodynamic forces, while Brownian hard spheres interact through both hydrodynamic and Brownian diffusion forces. Brownian hard spheres are non-aggregating colloidal particles [89].

In practice, narrowing or widening the particle size distribution is an effective way to control the viscosity of a suspension. Servais et al. (2002) [92] reported up to 50-fold reductions in shear viscosity by optimizing the particle size distribution, while maintaining the same solid/particle fraction $(\phi)$, which is described by the particle volume and defined by Equation (1).

$$
\phi=\frac{V_{\text {particle }}}{V_{\text {total }}}=\frac{V_{\text {particle }}}{V_{\text {particle }}+V_{\text {liquid }}}
$$


During a flotation operation, there are different parameters influencing its performance, including viscosity, density, particle size, clay content, and power input. All these parameters can affect the flotation performance in different degrees and are summarized in the Section 4 (at the end of the article).

\subsection{Fine Particle Flotation}

Natural resources are limited, and the availability of easily extractable ores is decreasing. The newly developing capability of beneficiating complex ores is thus in constant demand in order to selectively extract target minerals and maintain the sustainable use of mineral resources [2,93]. Complex ores are generally defined as ores that are difficult to treat using conventional metallurgical unit operations $[2,6,7]$. This difficulty is largely due to their complex mineralogy, which is often associated with the low degree of liberation and fine discrimination of target minerals [2]. Flotation of fine particles has therefore become particularly important in complex ore beneficiations, as advances in grinding are allowing low-grade mineral deposits to be economically exploited.

Moreover, mineral wastes, which are mainly constituted of fine particles, are becoming a critical issue for the mining industry because of environmental (e.g., acid mine drainage $[94,95]$ ) and economic concerns (e.g., recycling of tailings $[96,97])$. They can be processed by flotation or other separation methods to remove the problematic portions (e.g., arsenic) and recover the valuable materials (e.g., gold) [37].

Understanding the limits and challenges of fine particle flotation is thus an important key to achieve selective separation and recovery of fine particles. The key parameters in fine particle flotation include bubble size, particle aggregation, and flow conditions on fine particle flotation [35]. The flotation process involves interactions between particles and bubbles with three sub-processes, i.e., particle-bubble collision [98], attachment [99], and stability $[100,101]$. The flotation rate constant, and therefore the flotation recovery, are a function of the probability of these sub-processes [102,103].

Various reasons for the low flotation rate of fine particles are shown in Figure 3b; however, the fundamental reason is primarily due to their low collision efficiency with conventional flotation bubbles (e.g., 1200 to $1500 \mu \mathrm{m}$ ) and their rising velocity (e.g., 0.30 to $0.45 \mathrm{~m} / \mathrm{s}$ ) [104-106]. Decreasing bubble size can increase the bubble-particle collision and thus collection efficiency [106,107] and flotation rate [43,108], while it also has some disadvantages. They are: (1) the rising velocity of small bubbles is low with attached particles, and thus flotation time increases and requires a longer residence time in flotation circuits; (2) the lifting force of small bubbles can be too low to ensure process selectivity; and (3) increase in water recovery, due to (a) the bubble coalescence leading to the detachment of some particles from the bubbles and they may not be recovered in the concentrate $[104,109,110]$ and/or (b) small bubble size increasing residence time and thus entrainment [90].

Oil-assisted flotation is another approach to recover fine particles. It enlarges particle size by aggregation of fine mineral particles into floatable flocs by adding non-polar oils [111]. Hydrophobicity enhancement and oil bridging are the two major roles played by non-polar oils in hydrophobic flocculation [112]. The hydrophobic properties of non-polar oils in an aqueous mineral suspension allow it to preferentially attach and spread on the surface of naturally or collector-induced hydrophobic particles, leading to an oil layer coating and higher hydrophobicity. In addition, this "hydrophobic force" is stronger than the van der Waals force within a very short range of particle separation. As a result, the energy barrier of the interaction forces between two particles becomes significantly low, benefiting particles bridging into larger and stronger aggregates [111].

The coal-oil gold agglomeration (CGA) process is another approach to recover fine particles. It was developed by the British Petroleum (BP) research team in the early eighties [113] and is based on the natural hydrophobicity of coal and gold compared with most gangue materials [114]. It allows a selective recovery of hydrophobic gold particles attaching and penetrating into the pre-formed coal-oil agglomerates from an aqueous slurry. 
The coal-oil agglomerates form in a coal slurry and oil under intensive agitation enhances the homogeneous distribution of oil in fine spherical droplets and thus their collisions with coal particles. Furthermore, the oil droplets spreading on the coal surfaces form the "oil bridges" which combine the coal particles to agglomerate due to the interfacial tension of the oil and capillary attraction of the oil bridges between particles. Once coal-oil agglomerates form, they are added into gold-bearing ore slurry under intensive agitation; the gold particles thus collide, contact, and attach with the coal-oil agglomerates, and eventually penetrate into the agglomerates [115]. Then, the CGA agglomerates can be recovered by flotation or other methods (e.g., screening), dewatering to reject water and coal, and burning remained agglomerates to extract gold [36,113].

In hydrophobic aggregation, the fine particles are selectively hydrophobized by using the hydrophobic attraction between particles [112]. Intense agitation brings the particles in very close proximity, and hydrophobic forces keep them together. The existence of surfactants can enhance the hydrophobicity of fine particles surface and eliminate the hydration layer from the surface, reducing the hydration repulsion force at the same time [116]. For example, galena fines aggregated in the presence of xanthate ions [117], and the hydrophobic agglomeration of hematite fines was generated by sodium oleate [118].

Several other techniques proposed to overcome the issue of low collision efficiency of fine particles follow almost the same idea as that of oil-assisted flotation, i.e., enhancing particle-particle interaction by increasing particle size [104,119], inducing the fine particles to form flocs or aggregates. Depending on the mechanisms of aggregate formation, these techniques can be divided into three classes: (1) selective flocculation, (2) coagulation, and (3) hydrophobic aggregation [35,120].

Selective flocculation aggregates fines by adding long-chain organic polymeric reagents that bind the fine particles of one component together from the mixture by a bridging mechanism, and the aggregates are known as flocs. The polymers first adsorb onto mineral surfaces by electrostatic forces, specific chemical interaction, and/or hydrogen bonds followed by bridging other mineral particles and forming flocs.

Coagulation causes aggregation by adding simple electrolytes to compress particle electrical double layer which decreases the electrostatic repulsion between charged particles [84]. Coagulation is a much-used technique in water purification, where no selectivity is required, while in mineral separation, selectivity is essential. Electrolyte addition often causes heterocoagulation; however, it is very hard to obtain selective coagulation only by electrolyte addition. Therefore, this method is rarely used in particle size enlargement for mineral separation.

Table 1 summarizes different approaches adopted by different researchers to enhance fine particle flotation. The challenges in fine particle flotation will be further introduced and discussed in Section 2.2.

Table 1. Summary of several approaches adopted by different researchers to enhance fine particle flotation.

\begin{tabular}{ccc}
\hline Researcher & Approach Adopted & Findings \\
\hline Ahmed and Jameson (1985) [43] & Bubble size reduction & $\begin{array}{c}\text { The flotation rate constant of fine particles } \\
(<50 \mu \mathrm{m}) \text { increased up to five hundred-folds } \\
\left(1 \times 10^{-4} \text { to } 5 \times 10^{-2} \mathrm{~s}^{-1} \text { at } 300 \mathrm{rpm}\right) .\end{array}$ \\
\hline Yoon and Luttrell (1986) [106] & Bubble size reduction & $\begin{array}{c}\text { Particle-bubble attachment probability increased } \\
\text { with a decrease in the induction time and } \\
\text { maximum particle-bubble probability (0.92) was } \\
\text { recorded at 350 } \mu \text { bubble size at 10 msec } \\
\text { induction time. }\end{array}$ \\
\hline Hewitt et al. (1995) [121] & Bubble size reduction & $\begin{array}{c}\text { Smaller bubbles have higher attachment } \\
\text { efficiencies than do larger bubbles for all particle } \\
\text { sizes over a wide range of contact angles and } \\
\text { ionic strengths. }\end{array}$ \\
\hline
\end{tabular}


Table 1. Cont.

\begin{tabular}{|c|c|c|}
\hline Researcher & Approach Adopted & Findings \\
\hline Song et al. (2001) [120] & $\begin{array}{l}\text { Use of potassium amyl xanthate (PAX) } \\
\text { for the formation of flocs of galena } \\
\text { and sphalerite }\end{array}$ & $\begin{array}{l}\text { The floc flotation of galena and sphalerite fines } \\
(<20 \mu \mathrm{m}) \text { can reach floatability of } 100 \% \text {, in } \\
\text { comparison with conventional flotation } \\
\text { obtaining floatability of about } 40 \% \text {. For galena } \\
\text { and sphalerite, the optimum floc size was } 38 \mu \mathrm{m} \\
\text { and } 45 \mu \mathrm{m} \text {, respectively. }\end{array}$ \\
\hline Rubio et al. (2007) [122] & $\begin{array}{l}\text { Treatment of the copper / molybdenum } \\
\text { sulfide ore }(0.94 \% \mathrm{Cu} \text { and } 0.05 \% \mathrm{Mo}) \\
\text { using emulsified oil extender flotation. }\end{array}$ & $\begin{array}{c}\text { Copper and Molybdenum recovery of fine } \\
(37-5 \mu \mathrm{m}) \text { and ultrafine }(<5 \mu \mathrm{m}) \text { increased } \\
\text { around } 4 \% \text { to } 5 \% \text { and } 3 \% \text { to } 5 \% \text { respectively as } \\
\text { compared with a "standardized" mill } \\
\text { laboratory procedure. }\end{array}$ \\
\hline Otsuki and Yue (2017) [36] & $\begin{array}{l}\text { Adoption of CGA-assisted flotation to a } \\
\text { complex gold ore }\end{array}$ & $\begin{array}{l}\text { Higher gold recovery }(94.33 \%) \text { and grade } \\
(75.42 \mathrm{~g} / \mathrm{t}) \text { was achieved with the CGA process } \\
\text { as compared with the recovery }(92.44 \%) \text { and } \\
\text { grade }(36.63 \mathrm{~g} / \mathrm{t}) \text { in flotation without CGA, } \\
\text { especially in the fine particle fraction (between } \\
38-53 \mu \mathrm{m}) .\end{array}$ \\
\hline Arriagada et al. (2020) [123] & $\begin{array}{l}\text { Use of hydrophobized glass } \\
\text { bubbles (HGB) }\end{array}$ & $\begin{array}{l}\text { HGB addition increased the flotation kinetics } \\
\text { rate constant by } 1.4 \text { times and the maximum } \\
\text { recovery from } 64 \text { to } 90 \% \text { (considering a } \\
\text { first-order kinetics model). }\end{array}$ \\
\hline Farrokhpay et al. (2020) [124] & Use of nanobubbles & $\begin{array}{l}\text { When microbubbles were used, much less } \\
\text { collector (about half) was needed to achieve the } \\
\text { same or even slightly higher recovery. The } \\
\text { quartz flotation recovery increased from } 88 \text { to } \\
92 \% \text { with the use of microbubbles. }\end{array}$ \\
\hline Zhou et al. (2020) [125] & $\begin{array}{l}\text { Use of nano-scale bubbles generated by } \\
\text { hydrodynamic cavitation }(\mathrm{HC})\end{array}$ & $\begin{array}{l}\text { The separation efficiencies of conventional } \\
\text { flotation and flotation of ultra-fine coal } \\
\text { pre-treated via HC increased from } 2.62 \text { to } \\
\text { 3.62, respectively. }\end{array}$ \\
\hline Zhang et al. (2021) [126] & Use of nanobubbles & $\begin{array}{l}\text { The rutile treated with nanobubbles showed } \\
\text { higher recovery }(93 \%) \text { as compared with the } \\
\text { conventional bubbles, i.e., } 86 \% \text {. }\end{array}$ \\
\hline
\end{tabular}

\subsection{Challenges in Fine Particle Flotation}

The relationship between the physical and chemical properties of fine particles and their behavior in flotation is summarized in Figure $3 b$ [83]. The poor recovery of fine particles is often attributed to a low particle-bubble collision, because these particles follow the fluid streamlines around the rising bubbles [99,127-129]. Since fine particles have a higher surface area than coarse particles, more collectors for effective surface modification are needed and can be less selective for target particles [37]. Their momentum is quite small, and thus they tend to follow the water flow more easily than coarse particles. This results in a low flotation rate and less selective particle recovery, and therefore froth washing may be needed to address the extra entrainment [130].

In flotation, entrainment is a mechanical process by which fine mineral particles, typically below $10 \mu \mathrm{m}$, are recovered by the water flow, but not due to their attachment to the bubbles. In this entrainment process, both hydrophobic and hydrophilic particles can enter the froth zone and be transferred to the concentrate; therefore, resulting in poor mineral separation [6]. On the contrary, the true flotation process occurs when a particle collides with a rising bubble and is stably attached to its surface, and later on, removed from the cell as a part of the froth. Several methods and models have been proposed to distinguish entrainment from true flotation. The method of Trahar [131] determined the true flotation by the difference between two mineral batch flotation recoveries, with one 
recovery using only frother and the other using both frother and collector. Considering that the froth structure was different in the two situations, this method could not be considered an accurate one. Another method proposed by Warren was based on the effect of water recovery [42,132]. According to Warren's model, the recoveries of floatable $\left(R_{M}\right)$ and non-floatable $\left(R_{G}\right)$ particles can be summarized by Equations (2) and (3), below:

$$
\begin{gathered}
R_{M}=F_{M}+e_{M} \cdot W_{\text {water }} \\
R_{G}=e_{G} \cdot W_{\text {water }}
\end{gathered}
$$

where $F_{M}$ is the intercept on the mineral recovery axis in the plot of mineral/solid recovery $(\%)$ versus water recovery $(\%)$ by extrapolation to zero water recovery, representing the recovery by true flotation, as shown in Figure $5 ; e_{M}$ and $e_{G}$ are entrainment factors for floatable and non-floatable minerals, respectively; and $W_{\text {water }}$ is the weight of water recovered in a given time. In addition to Warren's model, the method developed by Mhonde et al. [133] assumed that the number of gangue particles reported to concentrate was solely due to entrainment when a high dosage of a depressant $(>500 \mathrm{~g} / \mathrm{t})$ was used [134].

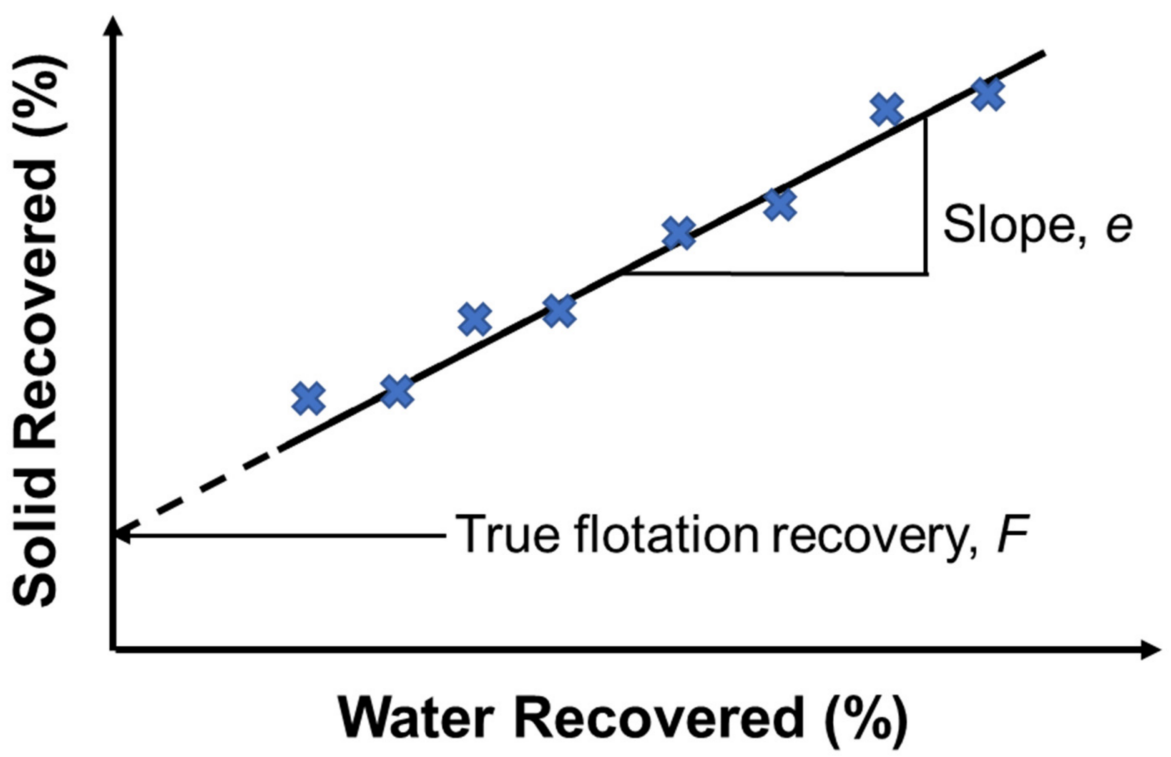

Figure 5. Determination of true flotation by the method of Warren. Redrawn and adapted from $[132,135]$.

Furthermore, fine particles have a strong influence on froth stability that decreases with increasing particle size and increases with decreasing particle size [136]. The dynamic froth stability defined as the equilibrium froth height in an aerated slurry [137] depends on the particle and bubble size, reagent adsorption, air flow rate, conditioning time, surface characteristics, and elemental composition [138]. The presence of fine particles increases the froth height and influences the dynamic froth stability. It was reported that the presence of $10 \mu \mathrm{m}$ galena particles can prolong the froth life of an alcohol aqueous solution from $17 \mathrm{~s}$ to several hours, whereas $30 \mu \mathrm{m}$ galena particles can only increase the froth life to $60 \mathrm{~s}$ [139]. Experiments using less than $0.7 \mu \mathrm{m}$ silica particles also showed more stable froth than $127 \mu \mathrm{m}$ [137] due to the particle size decrease [140]. However, a too-stable froth may increase the froth viscosity due to the presence of fine particles and it reduces the froth drainage effectiveness for selective rejection of the gangue particles back to the pulp and therefore increases the water recovery and particle entrainment $[37,60]$ against the true/ideal selective flotation.

Fine particles, especially clay minerals, normally have three negative effects on flotation. The first negative effect is the coating of clay minerals on valuable minerals. This prevents the selective adsorption of collectors on valuable minerals and reduces their 
selective flotation [141-144]. The second negative effect is the increase in pulp viscosity in the presence of a certain type of clay mineral (e.g., bentonite, kaolinite), which can result in a significant reduction in flotation recovery due to turbulence damping which results in lower particle-bubble collisions [145-149]. The third negative effect is the high entrainment of clay minerals due to low particle density leading to their slow particle settling velocity [150] and thus significant reduction of the grade of valuable minerals in flotation concentrates [151-153].

\section{Rheology}

Rheology is the study of the deformation and flow behavior of matter under an applied force and is widely applied to industrial, geological, and biological materials [62,154]. Knowledge of slurry/suspension rheology in mineral processing is in great demand for the optimization of flotation performances e.g., recovery and grade, due to the increasing need for processing complex ores with a high clay and fine mineral content [61]. The rheological behavior of mineral slurries is indicative of the level of inter-particle interaction or aggregation, and therefore, it can be used as a useful processing control parameter [46]. For example, rheology has been used to investigate particle-particle interactions in slurries of oxide minerals $[155,156]$, clay minerals such as talc [157-161], coal [162], sulphide minerals [163], and even gangue minerals such as silicates (including amphiboles and chlorites) in iron ores [164].

The flow properties of a fluid can be characterized by the plot of the shear stress as a function of a shear rate applied to the fluid, for example. Various observable behaviors are illustrated in Figure 6. In general, suspensions can exhibit either Newtonian or non-Newtonian behavior, including dilatant, plastic, pseudo-plastic, and Bingham behaviors [46] (Figure 6). A Newtonian fluid exhibits a linear increase in the shear stress with the shear rate. Two important rheological terms which are often associated with the rheology of fine/colloidal particle suspensions are: (1) yield stress, the intercept of the flow curve on the shear stress axis at zero shear rates [46]; and (2) viscosity, the shear stress applied to a fluid divided by the shear rate or a measure of fluid resistance to deformation at a given shear rate [165]. For a Newtonian fluid, the viscosity remains constant regardless of the applied shear rate, while for non-Newtonian fluids, it changes with shear rate [166]. Therefore, it should be specified at which shear rate a viscosity value was determined/measured. This specific viscosity is called the "apparent viscosity" or "apparent shear viscosity" [165].

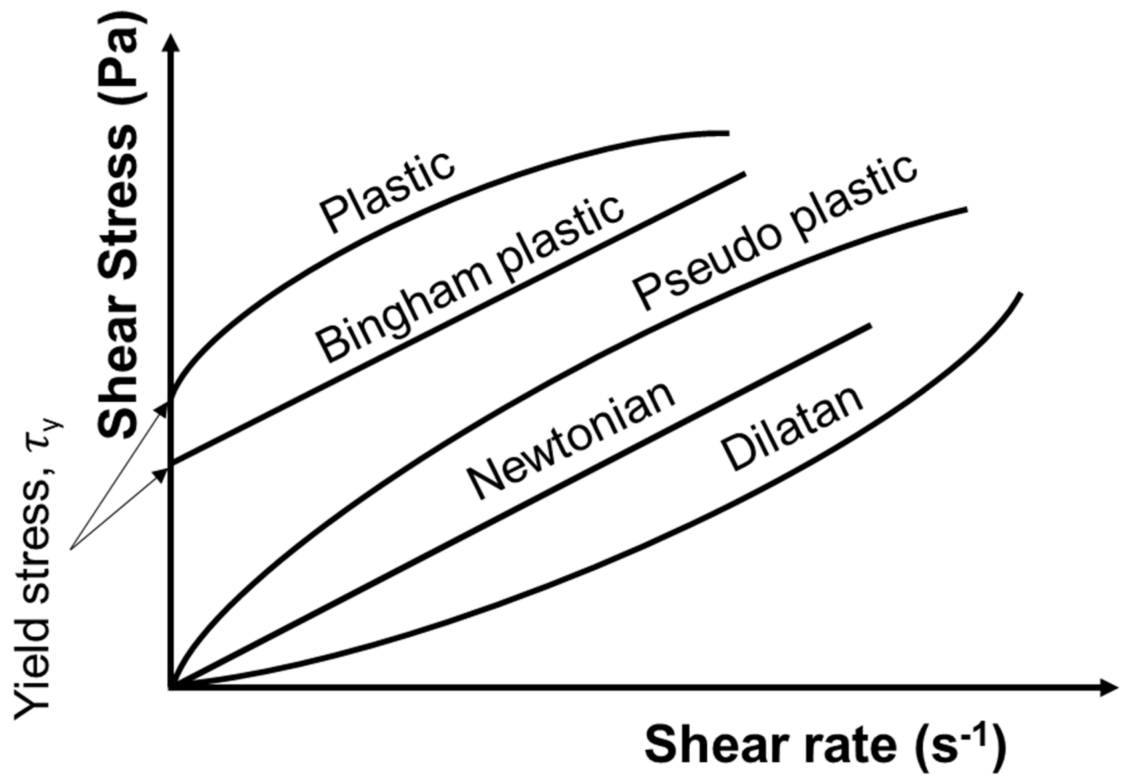

Figure 6. Shear stress behavior of different fluids as a function of shear rate. Redrawn and modified from [46]. 
In mineral processing industries, the rheological behavior of mineral particle suspension can influence mineral slurry transportation, ore grinding, and mineral separation (e.g., flotation) [61,163]. In the past, investigations on the rheological effect of mineral particles mainly focused on slurry transportation and ore grinding [46,61,62]. As low-grade and complex ores such as clayey and fibrous ores in large quantities are being processed due to the depletion of high-grade ores (both metallic and non-metallic) worldwide, the fine/ultrafine grinding for the liberation of valuable minerals is necessary and often leads to rheological difficulties (e.g., high viscosity) and complexities in the subsequent separation process, including flotation $[147,167]$. Thus, the importance of suspension rheology in the flotation system has been acknowledged.

In mineral processing, a proper dispersion of fine particles in an aqueous suspension plays an effective role in achieving selective enrichment of valuable minerals [168]. There are many techniques for evaluating those characteristics of fine particles, i.e., size measurement [169], turbidity measurement [170], contact angle measurement [171], zeta potential measurement [172], and force measurement $[173,174]$, as well as a combination of these measurements $[175,176]$. However, most of these measurements are not applicable for evaluating the characteristics in high solid concentrations [177]. As industrial practices, highly concentrated particle suspensions are treated in the separation of mineral fine particles as well as deposition of fine particles on fibers [176-180]. To investigate the degree of dispersion and coagulation of fine particles, rheological measurements can be applicable and conducted at high solid concentrations [168,181-183].

As mineral beneficiation mostly requires the separation of the fine particles in a water medium, it is very important to understand the behavior of the fine particles in the system of unit operations (e.g., flotation, thickening). The two important methods widely used for particle and particle suspension characterization are zeta potential and suspension rheology measurements [2]. Both of these methods are very useful for the understanding of particle coagulation/dispersion and suspension flow behavior, which affect the separation performance of targeted minerals from other gangue minerals [168]. Sections 3.1, 3.2 and 4 will introduce the basic concepts and modeling approaches in relation to fine particle dispersion/coagulation and flotation separation.

\subsection{Rheology of Fine Particle Suspensions}

Concentrated colloidal/fine particle (10 $\mathrm{nm}$ to $1 \mu \mathrm{m})$ suspensions are found in a wide range of daily products (e.g., milk, cosmetics) and industrial products/processes (e.g., mineral pulp, drug production). Precise understanding and manipulation of interactions within such a particle suspension and its resulting bulk behavior are thus of great interest and importance in both science and engineering [47].

Suspension rheology reflects the microscopic interactions among particles within a suspension/dispersion and shows the change in macroscopic behavior, such as an increase in the viscosity and/or yield stress due to the stronger particle interactions. Change in the viscosity can affect the process ability of a particle suspension/dispersion and thus process yield. The lower the viscosity by diluting a suspension, the higher the transportability, but few particles can be processed. On the other hand, increasing the particle concentration would increase the particle-particle interaction and the viscosity, and thus lower the transportability and could result in less process yield. In addition, so-called rheology modifiers can be used to maintain a reasonable process yield in many industrial applications, including mining and paintings. Apparently, many industries dealing with particle suspension/dispersion systems are interested in increasing the particle/solid concentration to aim for a higher productivity as well as effective waste/tailings management [47]. Figure 4 shows different physical, chemical, and mechanical parameters which influence the flotation performance and are discussed in detail below, especially in the aspect of mechanical parameters.

A mechanical flotation cell consists of a square or round tank that can be larger than $300 \mathrm{~m}^{3}$ in volume and agitated by an impeller incorporated in a rotor-stator assembly 
situated near the bottom of the cell [184]. FLSmidth's $660 \mathrm{~m}^{3}$ SuperCell ${ }^{\mathrm{TM}}$ at KGHM Robinson concentrator in the United States is the largest operating tank, followed by Outotec's $500 \mathrm{~m}^{3}$ TankCell $^{\circledR}$ at Boliden Kevitsa concentrator in Finland [184]. Air is introduced into the rotor-stator assembly, either by induced air suction (induced-air) or by an external blower (forced-air). The level of agitation has a profound effect on flotation in mechanical flotation cells. Agitation is responsible for creating a suitable hydrodynamic environment in the cell for efficient gas dispersion, particle suspension, and flotation [185]. Hydrodynamics is a broad term used to describe fluid flow. In a mechanical flotation cell, it is largely driven by the action of the impeller which establishes a flow pattern, or average path of the bulk fluid flow. Flow patterns are governed by vessel characteristics, such as size and shape, and impeller properties such as geometry and rotational speed. The fluid leaves the impeller in axial, radial, and tangential fluid jets which carry kinetic energy, in the form of fluid flow, into the bulk flotation cell where they ultimately decay into turbulence and circulate back to the impeller [186]. The effects of agitation on flotation can be considered from two levels. At a macroscopic level, agitation is responsible for creating a suitable hydrodynamic environment in the cell for efficient gas dispersion, particle suspension, and flotation. At a microscopic level, agitation results in turbulence which is responsible for the elementary sub-processes of bubble breakup, particle dispersion, and particle-bubble contact [187].

Deglon [185] investigated the influence of agitation on the flotation of platinum ores $\left(d_{40}=75 \mu \mathrm{m}\right)$ with reference to a result from a test on $60 \mathrm{~L}$ pilot-scale mechanical flotation cells on South African platinum concentrators. He showed that the recovery increased from 53 to $77 \%$ with the increase in impeller speed from 850 to $1300 \mathrm{rpm}$. He discussed their results with the increase in impeller speed turbulence in the flotation cell increases which improves particle-bubble contact.

The suspension viscosity, affected by the presence of fine/ultra-fine particles as well as the clay minerals [188], also influences the flotation performance in terms of the recovery and grade. The suspension viscosity is affected by the solid concentration, shear rate, and particle size [89,189]. A higher pulp viscosity usually corresponds to a lower recovery of valuable minerals. In the pulp zone of a flotation cell (Figure 3a), a high pulp viscosity can result in increased turbulence damping, poor gas dispersion, reduced mobility of particles and mineralized bubbles, and a low particle-bubble collision efficiency [148,190]. All of these factors can lead to a reduced flotation efficiency.

Farrokhpay et al. (2016) [191] studied the behavior of swelling clays versus nonswelling clays in flotation, and they found out that copper recovery decreased drastically (from 90 to $80 \%$ ) in the presence of $15 \mathrm{wt}$.\% swelling clay, montmorillonite, while in the presence of $15 \mathrm{wt}$ \% non-swelling clays, illite and kaolinite, the copper recovery decreased slightly to $87 \%$ and $88 \%$, respectively. The copper grade decreased from 18 to $1 \%$ in the presence of $30 \mathrm{wt} . \%$ and $15 \mathrm{wt} . \%$ of kaolinite and montmorillonite, respectively, and to $5 \%$ in the presence of $30 \mathrm{wt} \%$ illite. They reported the apparent viscosity of the ore slurry in the presence of $15 \mathrm{wt}$ \% montmorillonite, $30 \mathrm{wt} . \%$ of kaolinite, and $30 \mathrm{wt} \%$ illite at a shear rate of $100 \mathrm{~s}^{-1}$ as $0.17,0.03$, and $0.02 \mathrm{~Pa}$ s, respectively. Chen et al. (2017) [192] reported the decrease in copper flotation recovery from 95 to $63.6 \%$ with an increase in pulp viscosity from 0.109 to $0.147 \mathrm{~Pa} s$ in the presence of 30 and $50 \mathrm{vol} . \%$ of amorphous silica (in amorphous silica and quartz suspension), respectively.

In flotation, $\mathrm{pH}$ control is a vital method to control selective mineral separation. In practice, the $\mathrm{pH}$ of flotation slurries is most commonly regulated by lime, as it is readily available and the most economical $\mathrm{pH}$ regulator in use. In addition, lime is known as an effective depressant for iron sulfides (especially for pyrite), inducing flotation selectivity in favor of other metal sulfides, which are often present in the same sulfide ores [56]. Gibson and Kelebek (2014) [193] also reported that lime acts as a depressant for pentlandite, while in the presence of the other $\mathrm{pH}$ modifier (i.e., soda ash), pentlandite recovery was maintained at a high value of $93 \%$. In the case of lime, it releases $\mathrm{Ca}^{2+}$, which can interact with the minerals and depress their flotation behavior. 
The ore suspension can be either alkaline or acidic [194]. A litmus paper or a $\mathrm{pH}$ meter can be used to measure $\mathrm{pH}$. The surface chemistry of most minerals is affected by the solution $\mathrm{pH}$. In general, minerals develop a positive surface charge under acidic conditions and a negative charge under alkaline conditions. For example, chalcopyrite mineral particles possess a positive charge up to $\mathrm{pH} 5.5$, and above this $\mathrm{pH}$, they possess a negative charge [172]. Since surface charge of each mineral changes from positive to negative at a certain $\mathrm{pH}$, it is possible to manipulate the attraction of collectors to their surfaces by $\mathrm{pH}$ adjustment. Sasaki et al. (2010) [195] reported that chalcopyrite $\left(\mathrm{CuFeS}_{2}\right)$ flotation strongly depends on the pulp $\mathrm{pH}$. Under collectorless conditions, chalcopyrite recovery decreases with the increase in $\mathrm{pH}$ (i.e., 82,60 , and $40 \%$ at $\mathrm{pH} 2,5$, and 11 , respectively). Göktepe (2002) [196] noticed that the recovery of sphalerite with potassium amyl xanthate (KAX) decreased from 83 to $22 \%$ with the increase in $\mathrm{pH}$ from 6 to 8 .

There are different complementary methods with rheological measurements (scattering, imaging), in terms of enhancing the understanding of microscopic particle-particle interactions that can explain the macroscopic particle suspension rheological behaviors. Scattering reflects the shape and size of scatters (colloidal particles), as well as the scattering contrast and volume, characteristic lengths, and the surface area-to-volume ratio [197]. These properties can be modified by changing the microscopic interaction between particles within a suspension/dispersion that can change macroscopic behavior, such as an increased suspension viscosity/yield stress that is a useful factor to formulate and manipulate a colloidal product [168].

\subsection{Zeta Potential of Fine/Colloidal Particles}

Particle surface charge is an important particle property that can change the microscopic particle-particle interactions and eventually the macroscopic particle suspension behaviors. Zeta potential is the practically measurable particle surface charge through a dilute suspension using electrophoresis [198]. It modifies the interactions between a particle and surfactant molecules (e.g., collector, depressants, dispersant in froth flotation systems) to modify the surface wettability of particles $[199,200]$ and thus to properly manipulate the particle behavior for achieving a better separation with the aid of air bubbles in froth flotation system. For example, a negatively charged mineral surface attracts cationic collectors. It can also determine mineral-mineral interactions [183], which significantly affect mineral flotation performance. For example, oppositely charged particles attract each other while the same charged particles repel [2].

An electroacoustic method for determining zeta potential that uses the sound waves generated from the particle movement under an AC (Alternative Current) field was developed [201]. This method allows us to perform the measurements in concentrated suspensions that are commonly treated in process plants, while the conventional electrophoresis methods require a diluted suspension. The potential drawback of this dilution is that it could overlook the particle coagulation happening in a concentrated suspension [168].

When minerals are comminuted from their ores via an aqueous processing route, suspensions of fine $(\leq 1 \mu \mathrm{m})$ or colloidal particles can be generated. Such particles are often small enough to be unaffected by gravity, and as a result, their interactions are dominantly controlled by a range of attractive and repulsive inter-particle forces [202] DLVO (Derjaguin-Landau-Verwey-Overbeek) theory is one of the best-known theories for describing the particle-particle interactions with the summation of the van der Waals potential energy $\left(V_{\mathrm{VDW}}\right)$ and electrical double layer potential energy $\left(V_{\mathrm{EDL}}\right)[166,203,204]$. If the total potential energy $\left(V_{\mathrm{T}}=V_{\mathrm{VDW}}+V_{\mathrm{EDL}}\right)$ is high and positive, particles repel each other; otherwise, particles attract each other. This is a straightforward theory that can explain particle coagulation/dispersion in different colloidal systems [205-208].

The van der Waals force is short-range but universal in any colloidal suspension/dispersion system. The origin of this force is the instantaneous dipole interactions within atoms/molecules in neighboring particles. The nature of this interaction is attractive due to the correlation between dipoles to minimize their interaction energy [209]. The van der Waals force is 
normally independent of suspension conditions such as $\mathrm{pH}$ and the presence of surfactant/polymer, except particle size and high electrolyte concentration [202].

The electrical double layer force is the result of ion concentration between neighboring particle surfaces due to overlapping the double layer formed around the particle surface and thus increase in osmotic pressure and free energy [209]. Suspension pH can vary the zeta potential and thus the electrical double layer force. This force is repulsive in a similar particle system, while it can be either repulsive or attractive in a dissimilar particle systems, depending on the sign and magnitude of particle surface charges.

For two similar particles of radius " $a$ " separated by distance " $H$ ", where $a>>H$, the van der Waals force $\left(F_{\mathrm{VDW}}\right)$ [209] and the electrical double layer force $\left(F_{\mathrm{EDL}}\right)$ [210] can be given as Equations (4) and (5), respectively:

$$
\begin{gathered}
F_{\mathrm{VDW}}=-\frac{A_{\mathrm{H}}}{12 H^{2}} \\
F_{\mathrm{EDL}}=\frac{2 \pi \varepsilon_{0} \varepsilon k \zeta^{2} \exp (-\kappa H)}{1+\exp (-\kappa H)} \\
\kappa=\left(\frac{2 z^{2} n_{o} e^{2}}{\varepsilon_{0} \varepsilon k_{B} T}\right)^{1 / 2}
\end{gathered}
$$

where $A_{\mathrm{H}}$ is the Hamaker constant, $H$ is the inter-particle separation distance, $\varepsilon$ is the dielectric constant of the medium, $\varepsilon_{0}$ is the permittivity of free space, $\zeta$ is the zeta potential, $\kappa$ is the Debye-Huckel reciprocal length defined in Equation (6), where $n_{0}$ is the number concentration of ions, $z$ is the ionic valence, $e$ is the elementary charge, and $T$ is the absolute temperature, $k_{\mathrm{B}}$ is the Boltzmann constant. The above equations are the major equations used in the coupling DLVO forces and suspension yield stress [211-213].

To test the applicability of DLVO theory to a concentrated particle suspension system, rheological measurements are often made to determine the shear yield stress $\tau_{\mathrm{y}}$, which is plotted as a function of the square of the zeta potential $\left(\zeta^{2}\right)$ [168]. If the DLVO interactions govern the particle-particle interactions, there should be a linear correlation between those two values, as given below in Equation (7), and typical plots are given in Figure 7a:

$$
\tau_{\mathrm{y}}=\tau_{\mathrm{y}(\max )}-k \zeta^{2}
$$

where $\tau_{\mathrm{y}}$ is the shear yield stress, $\tau_{\mathrm{y}(\max )}$ is the maximum shear yield stress value at the isoelectric point (IEP), and $k$ is a constant. This correlation can be explained by the stronger contribution of the van der Waals force over the weakest electrostatic repulsion at IEP $(\zeta=0)$ as depicted in Figure $7 \mathrm{~b}, \mathrm{c})$ [174]. Leong and Ong (2003) [211] also claimed that the value of the intercept between the extrapolated line and $\zeta^{2}$ axis indicates the square of critical zeta potential $\left(\zeta_{c}^{2}\right)$ that shows the flocculation-dispersion transition. In other words, particles flocculate below this critical zeta potential, while they disperse above that due to the electrostatic repulsion. 


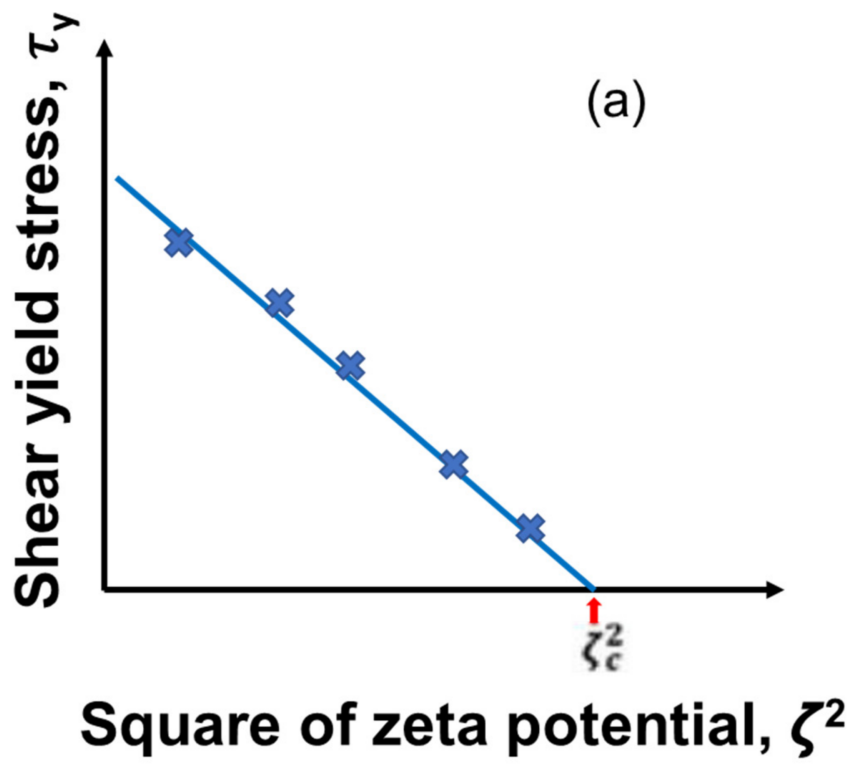

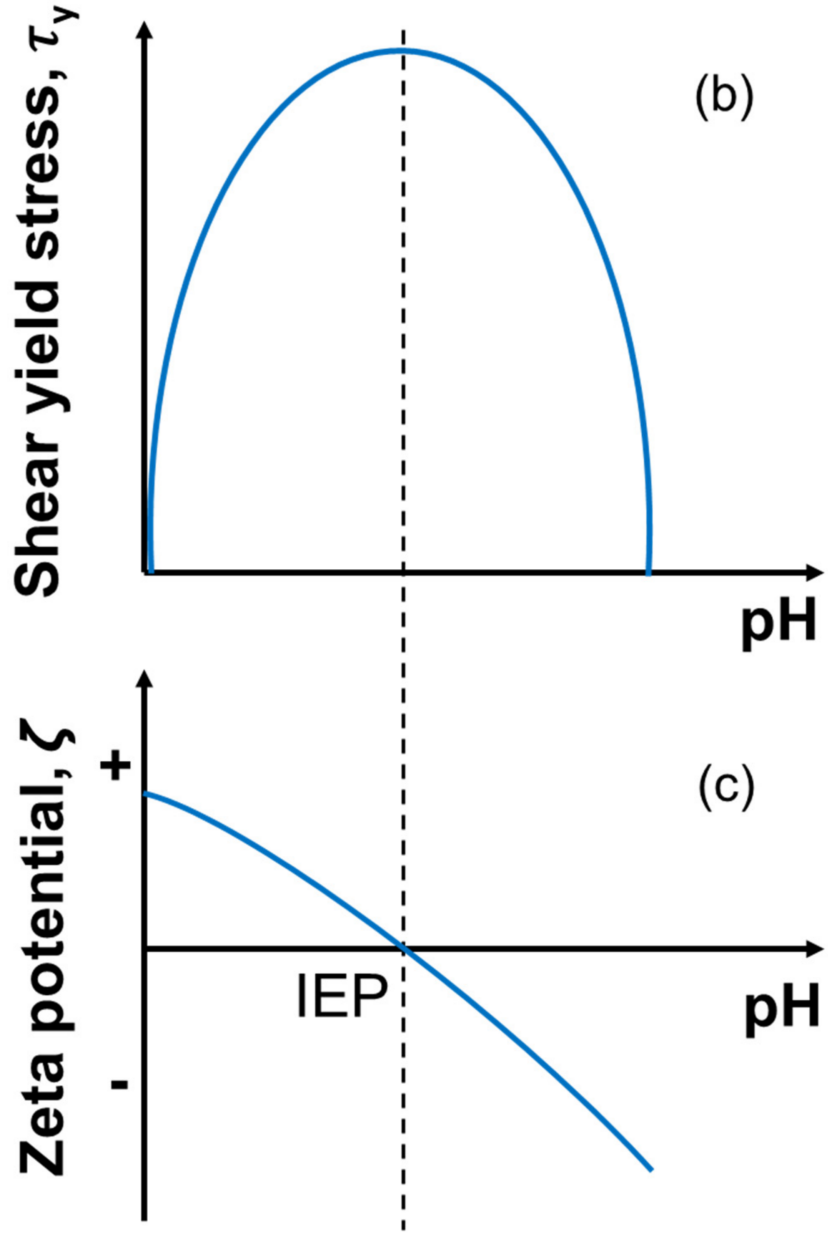

Figure 7. Typical correlation between the shear yield stress and the electrostatic interaction characterized by zeta potential for a homogeneous charged inorganic particle suspension. (a) The shear yield stress as a function of the square zeta potential, (b) the shear yield stress as a function of $\mathrm{pH}$, and (c) zeta potential as a function of $\mathrm{pH}$. Redrawn and modified with permission from [213]. Copyright 2021 Wiley Analytical Science.

\section{Correlation between Rheology and Flotation}

Figure 8 indicates the relevant literature on rheology-flotation correlation in froth and pulp regions in order to show the population of relevant studies and point out research gaps. Table 2 shows the important basic equations, aims/findings, limitations, and challenges of the reported works by different researchers. Rheological investigations can be used to understand the particle-particle interactions occurring in the flotation processes [214]. Rheology can also be studied to suggest the improvement potential in fine particle flotation [215]. To achieve selective fine particle flotation, a substantial dispersion state (often characterized by low suspension viscosity) is required, resulting in a reduction in damping and turbulence. It also helps to increase particle-bubble attachment, as well as decreasing their detachment while enhancing the ultrafine particle floatability [216]. In flotation plants, experienced operators even use their fingers to test whether the froth is viscous and needs adjustment of the operating variables to reduce the viscosity [58]. The rheological characteristics should also be carefully considered in reagent selection in order to achieve selective collector adsorption on mineral flotation processes. For example, the flow properties and apparent viscosity of mineral slurries are sensitive to the use of chemical additives [49]; using proper dispersants and viscosity modifiers can help to disperse slimes, reduce pulp viscosity, and therefore improve the flotation recovery and selectivity [217]. 


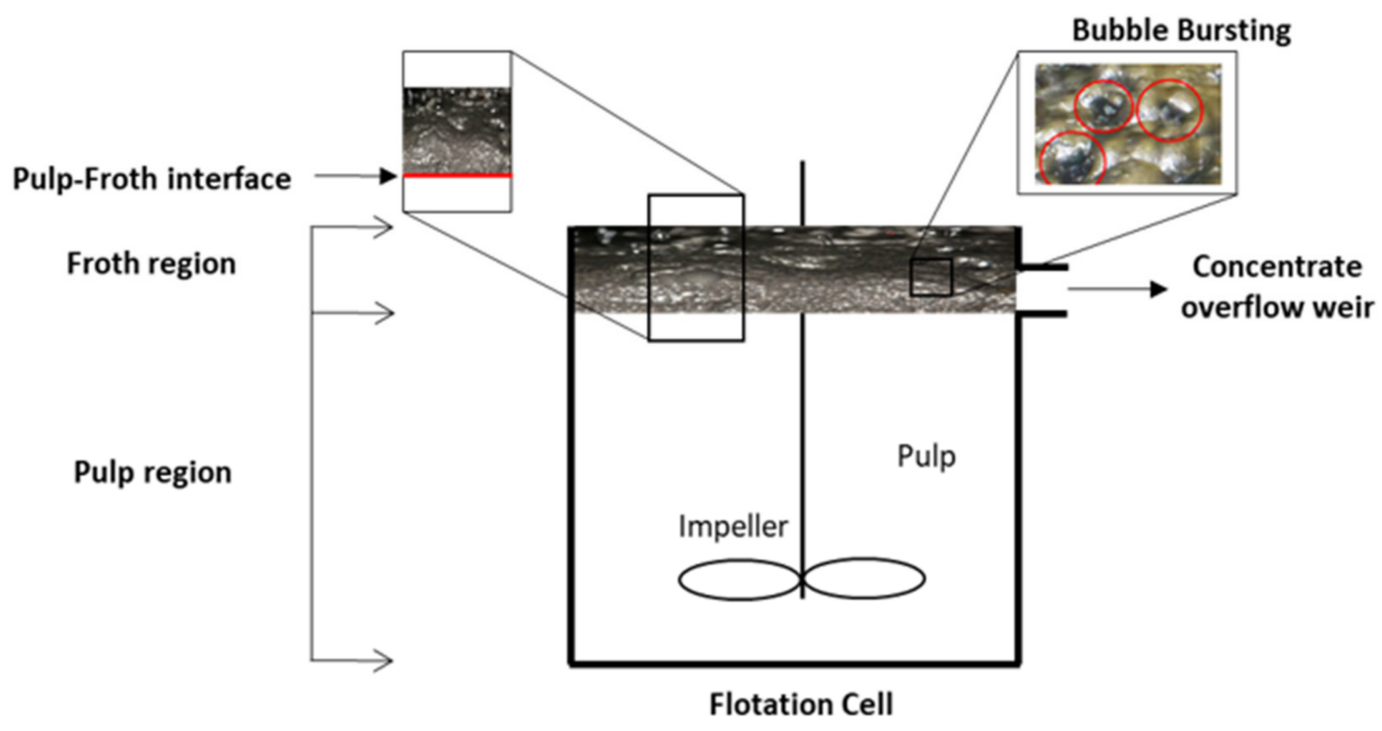

Figure 8. Schematic explaining the two main regions (pulp and froth) in a flotation cell and the bubble bursting in the froth zone and relevant literature in each region from rheology point of view. The image on bubble bursting was obtained from Otsuki and Miller (2018) adapted from [14].

The rheology of flotation pulp is a complex function of the physical and chemical properties of the continuous and discrete phases at the scale of mineral particles. The principal factors affecting pulp rheology include solid fraction, particle characteristics (e.g., shape, size), and interactions between particles and their associated variables such as shear rate (agitation speed) and pulp chemistry (e.g., pH, ions, surfactant molecules) $[57,148,191,218-224]$. These influencing factors often combine to determine the rheological behavior of flotation pulps [62]. For example, the presence of different types of clays in flotation may result in negative impacts on pulp and froth rheology. Increasing the content of clays in pulp would increase pulp viscosity regardless of clay type, while it may not be the case for the froth rheology [62]. The hydrophilicity and the swelling characteristics of clays could increase froth viscosity with their contents [191].

Froth properties are also very important in determining the flotation performance, and rheology is an important froth property, because it can affect both froth mobility and stability [46], which are two important properties of froth in flotation [149,191,217,225-228]. Froth mobility comprises the vertical motion of the froth from the interface between the pulp and the froth, and also the horizontal motion towards the concentrate overflow weir. Froth stability describes the processes, including bubble bursting, particle detachment, and drainage of water and solids from the froth, as shown in Figure 8. They occur within the froth while it is flowing [58].

It can be stated that pulp rheology and froth rheology synergistically influence the flotation performance as a whole. Consequently, comprehension of the correlation between pulp and froth rheology becomes particularly necessary in respect of adjusting flotation variables to optimize/maximize flotation performance. However, no comprehensive studies on this correlation have been reported yet (Figure 8) possibly due to its complexity and/or lack of this perspective. In addition, modeling flotation performance incorporating suspension rheology still needs more advancement as seen in Table 2 although there are many experimental works reported without modeling [149,191,192,218-221,229]. 
Table 2. List of previous studies discussing rheology-flotation correlation.

\begin{tabular}{|c|c|c|c|}
\hline Researcher & Type of Modeling Approach & Aims and Challenges & Findings and Limitations \\
\hline $\begin{array}{l}\text { Schubert and Bischofberger, } \\
1978 \text { [187] }\end{array}$ & $\mathrm{N} / \mathrm{A}$ & $\begin{array}{l}\text { - To investigate the effects of change in hydrodynamics conditions on } \\
\text { the cassiterite flotation recovery. }\end{array}$ & $\begin{array}{l}\text { With the increase in power input, the recovery of cassiterite mineral particles increased due to the increase in the number of } \\
\text { collisions between particles and bubbles keeping in view that the increasing detachment forces has no importance for small ore } \\
\text { particles } 1 \text { <100 un m. } \\
\text { The increasing local energy dissipation decreased the bubble size and thus the bubble numbers as well as their surfaces available } \\
\text { for the attachment of particles also increased. }\end{array}$ \\
\hline $\begin{array}{l}\text { Schubert and Bischofberger, } \\
1998[188]\end{array}$ & $\mathrm{N} / \mathrm{A}$ & To study the factors affecting micro processes in the flotation. & 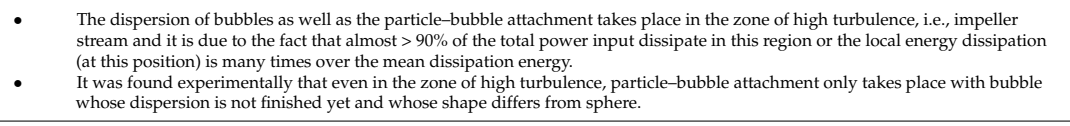 \\
\hline Schubert, 1999 [228] & $\mathrm{Z}_{B P}=5 n p n_{b} d_{p b}^{2} \sqrt{\sqrt{v_{p}^{\prime 2}+v_{b}^{\prime 2}}}(8)$ & To understand the effect of turbulence damping by fine particles. & 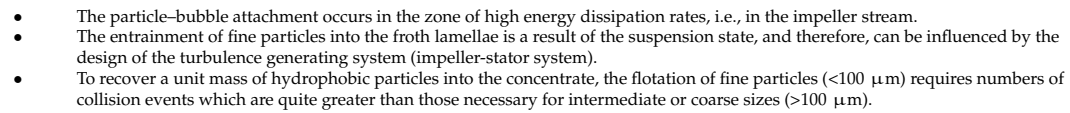 \\
\hline \multirow{4}{*}{ Pyke et al, $2003[104]$} & 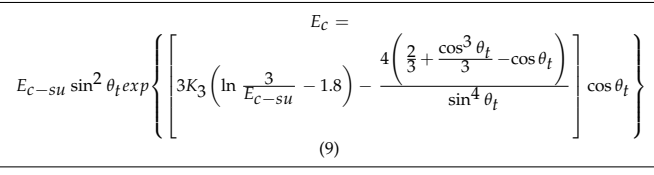 & \multirow{4}{*}{ 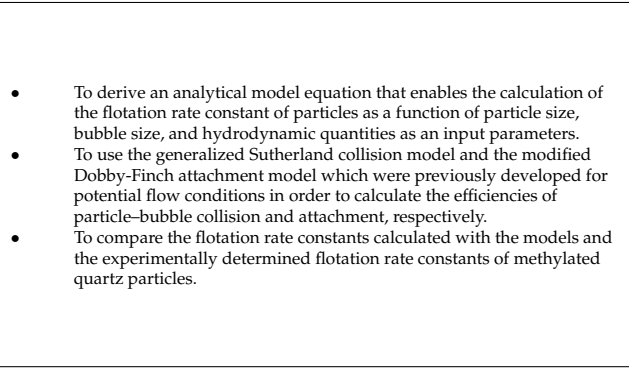 } & \multirow{4}{*}{ 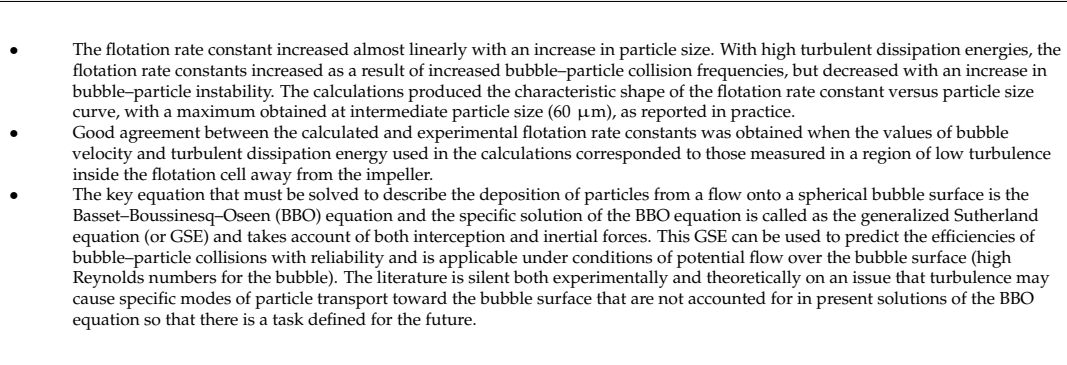 } \\
\hline & $E_{a}=\frac{\sin ^{2} \theta_{a}}{\sin ^{2} \theta_{t}} \quad(10)$ & & \\
\hline & $E_{S}=1-\exp \left(1-\frac{1}{B_{0}^{*}}\right)$ & & \\
\hline & $\frac{d N_{p}}{d t}=-2.39 \frac{G_{f r}}{d_{b} V_{c e l}}\left[\frac{0.33 \epsilon^{4 / 9} d_{b}{ }^{7 / 9}}{v^{1 / 3}}\left(\frac{\Delta \rho_{b}}{\rho_{f l}}\right)^{=2 / 3} \frac{1}{v_{b}}\right] \times E_{C} E_{a} E_{s} N_{p}$ & & \\
\hline Shabalala et al., 2011 [149] & N/A & $\begin{array}{l}\text { - To investigates the effect of slurry rheology on gas dispersion using } \\
\text { three different ores in a } 100 \mathrm{~L} \text { pilot-scale Batequip mechanical } \\
\text { flotation cell. }\end{array}$ & 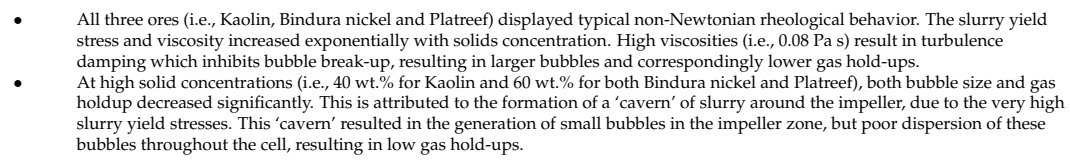 \\
\hline Gencet al., 2012 [217] & N/A & $\begin{array}{l}\text { To study the effect of pulp rheology on flotation of nickel sulphide ore } \\
\text { with fibrous gangue particles. }\end{array}$ & $\begin{array}{l}\text { - The suspension viscosity increased from } 0.048 \text { to } 0.15 \text { Pa s with the increase in solid concentration of nickel sulphide ore from } 15 \\
\text { to } 20 \text { wt.\%, at a shear rate of } 40 \mathrm{~s}^{-1} \text { - } \\
\text { The nickel recovery decreased from } 78 \text { to } 68 \% \text { with the increase in suspension viscosity from } 0.048 \text { to } 0.15 \text { Pa s. }\end{array}$ \\
\hline Patra et al., 2012 [150] & & $\begin{array}{l}\text { - To investigate the impact of pulp rheological behavior on selective } \\
\text { separation of Ni minerals from fibrous serpentine ores. }\end{array}$ & 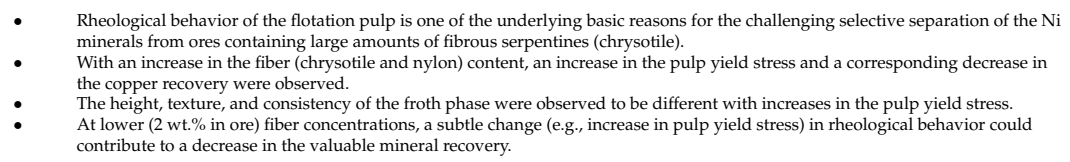 \\
\hline Xu et al., 2012 [225] & $R_{t}=R_{\max }(1-\exp (-k t))$ & 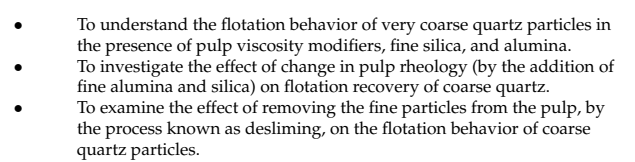 & $\begin{array}{l}\text { Fine particles attachment depressed the coarse particle recovery by decreasing the mean contact angle. } \\
\text { Increase in pulv viscosity due to fine particles depressed the coarse particle recovery due to the dominant effect of fine particle } \\
\text { attachment which decreased the hydrophobicty of coarse particles. } \\
\text { Desliming fine hydrophilic particles restored the recovery of coarse particles to a certain degree probably due to an increase in the } \\
\text { contact angle of coarse particles. }\end{array}$ \\
\hline
\end{tabular}


Table 2. Cont.

\begin{tabular}{|c|c|c|c|}
\hline Researcher & Type of Modeling Approach & Aims and Challenges & Findings and Limitations \\
\hline Forbes et al., 2014 [57] & $f(t)=\eta+\varphi \cdot e^{\left(-k_{f} t\right)}+(1-\varphi-\eta) \cdot e^{\left(-k_{s} t\right)}$ & $\begin{array}{l}\text { - Decouple and estimate the relative magnitudes of (a) the slime } \\
\text { coatings and bl pulp rheology effects on the natural floatability of } \\
\text { chalcopyrite in a model mineral system. }\end{array}$ & $\begin{array}{l}\text { - The increase in flotation pulp rheology and the effect of slime coatings were both identified as present. However, the slime } \\
\text { coatings effect could not be completely isolated from the rheological effect, as the two are inherently related. } \\
\text { The eatemptt to quantify the deggree of interaction between chalcopyrite and kaolinite using zeta potential distributions was not } \\
\text { successful due to the nature of the measurement technique. } \\
\text { Factors such a w water quality, the liberation of composite ore particles, and the presence of reagents need to be taken into account } \\
\text { in future work. }\end{array}$ \\
\hline Cruz et al., 2015 [230] & $\mathrm{N} / \mathrm{A}$ & $\begin{array}{l}\text { - To investigate the interaction of two clay minerals, kaolinite, or } \\
\text { bentonite with gypsum and its effects on the flotation of a } \\
\text { copper-gold ore. }\end{array}$ & 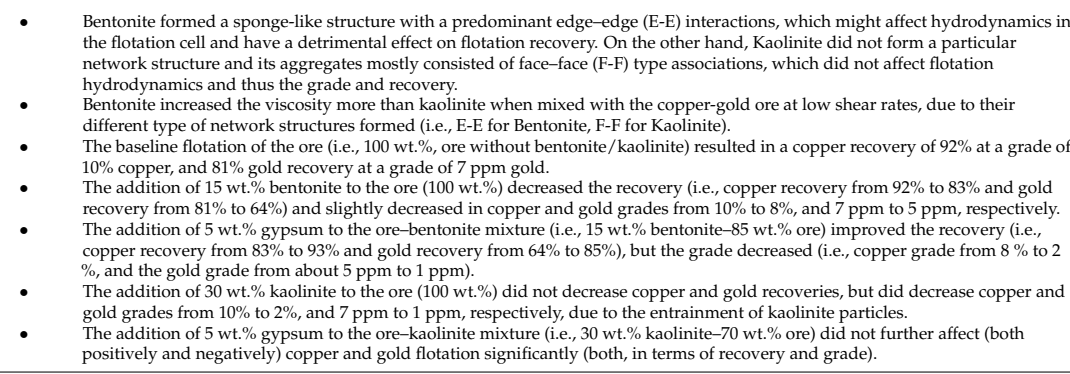 \\
\hline Wang et al., 2016 [224] & $\mathrm{N} / \mathrm{A}$ & $\begin{array}{l}\text { - To investigate the effect of different cations, } \mathrm{Na}^{+}, \mathrm{K}^{+}, \mathrm{Mg}^{2+} \text {, and } \\
\mathrm{Ca}^{2+} \text { with the same anion, } \mathrm{Cl}^{-} \text {, on the rheology of a copper-gold ore } \\
\text { in the presence of bentonite, and the copper flotation. }\end{array}$ & 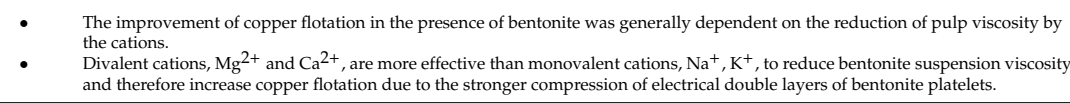 \\
\hline Zhang and Peng, 2015 [226] & ENT $T^{\text {con:tail }}=\frac{\frac{M_{\text {gangue }}}{M_{\text {wageter con }}}}{\frac{M_{\text {gangue }}}{M_{\text {water tail }}}} \quad(15)$ & $\begin{array}{l}\text { - To investigate the effect of bentonite and kaolinite minerals with low } \\
\text { and high crystalinity on pulp rheology and the flotation of copper } \\
\text { and gold minerals. }\end{array}$ & $\begin{array}{l}\text { It was found that clay mineral particle interactions in the flotation system dominated the pulp rheology. } \\
\text { The presence ef clay minerals increased pulp viscosity; copper recovery decreased as pulp viscosity increased; a slight increase in } \\
\text { pulp viscosity increased gold recovery but further increasing the pulp viscosity reduced gold recovery. }\end{array}$ \\
\hline Zhang et al., 2015 [223] & $\mathrm{N} / \mathrm{A}$ & $\begin{array}{l}\text { To investigate the flotation of a copper-gold ore in the presence of } 10 \\
\text { wt.\% bentonite in tap water and seawater. }\end{array}$ & $\begin{array}{l}\text { Copper recovery and grade decreased with increasing pulp viscosity by bentonite, use of seawater (salt ions) reduced pulp } \\
\text { viscosity in the presence of bentonite and improved copper and gold recoveries by improving bubble and particle mobility. }\end{array}$ \\
\hline Farrokhpay et al., 2016 [192] & $\mathrm{N} / \mathrm{A}$ & $\begin{array}{l}\text { - To understand the different effects of swelling and non-swelling clays } \\
\text { on the flotation of copper ore through heamining the grade and } \\
\text { recovery, pulp rheology, and froth characterisitics. }\end{array}$ & $\begin{array}{l}\text { - Swelling clays (i.e., Montmorillonite) can adversely affect the flotation performance mainly via adsorbing water which changes } \\
\text { the rheology and froth stability, reducing both flotation grade and recovery. } \\
\text { Non-swelling clays (i.e, kaolinite and illite) had a lower effect on the rheology. } \\
\text { Kaoliniti increased the froth stabilitity and reduced the flotation grade but illite showed the least effect on the flotation } \\
\text { performance. }\end{array}$ \\
\hline Wang et al., 2015 [221] & $\mathrm{N} / \mathrm{A}$ & $\begin{array}{l}\text { To comprehend the effect of clay minerals on slurry rheology and thus } \\
\text { on copper flotation. }\end{array}$ & 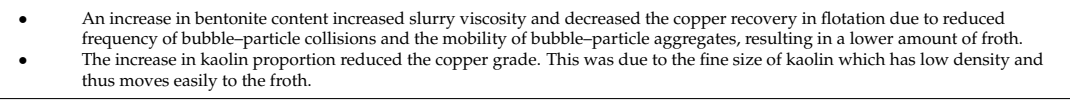 \\
\hline Basnayaka et al., 2017 [227] & $R=R_{\infty}\left[1-\frac{\left(1-e^{-k_{\max } t}\right)}{k_{\max t}}\right]$ & $\begin{array}{l}\text { - To investigate the influence of kaolin and bentonite clays on the } \\
\text { flotation of gold-bearing pyrite in a gold ore. } \\
\text { To study the changes in rheological properties of the flotation pulp } \\
\text { under normal operating conditions with the additions of kaolin and } \\
\text { bentonite clays at various solid concentrations. }\end{array}$ & $\begin{array}{l}\text { - It was found that bentonite clay reduced the pyrite recovery, and modified the pulp rheology more than kaolin. } \\
\text { The addition of } \mathrm{Ca}^{2+} \text { to the pulp containing bentonite improved the pyrite flotation recovery by its ability to modify the } \\
\text { rheological characteristics as } \mathrm{Ca}^{2+} \text { suppress the swelling properties of bentonite, and alters the surface charge properties of } \\
\text { bentonitic clay particles. } \\
\text { It was suggested that masurements of rheological properties and evaluating their correlations with flotation parameters may be } \\
\text { used to routinely monitor the flotation performance in operating plants when processing ores with significant amounts of clay. }\end{array}$ \\
\hline
\end{tabular}


Table 2. Cont.

\begin{tabular}{|c|c|c|c|}
\hline Researcher & Type of Modeling Approach & Aims and Challenges & Findings and Limitations \\
\hline Chen et al., 2017 [193] & $\mathrm{N} / \mathrm{A}$ & $\begin{array}{l}\text { - To investigate the effect of amorphous silica on pulp rheology and } \\
\text { chalcopyrite flotation. }\end{array}$ & 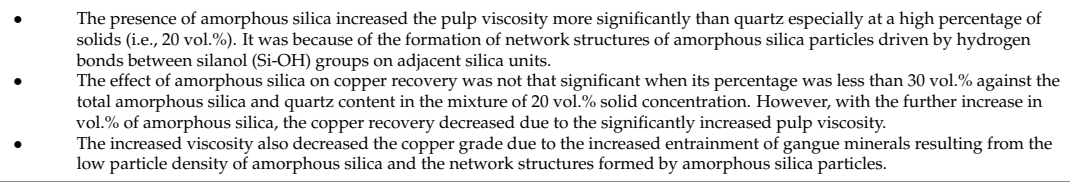 \\
\hline Farrokhpay et al., 2018 [222] & N/A & $\begin{array}{l}\text { - To investigate the effect of talc and muscovite on the flotation of } \\
\text { copper ore. }\end{array}$ & 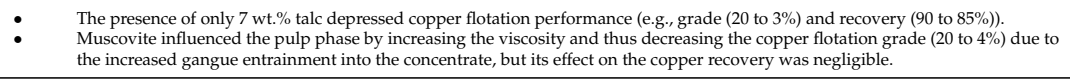 \\
\hline Liu et al., 2018 [229] & N/A & $\begin{array}{l}\text { - To identify yarious mechanisms responsible for the poor flotation of a } \\
\text { high-clay content gold ore and then develop a remedial solution. }\end{array}$ & 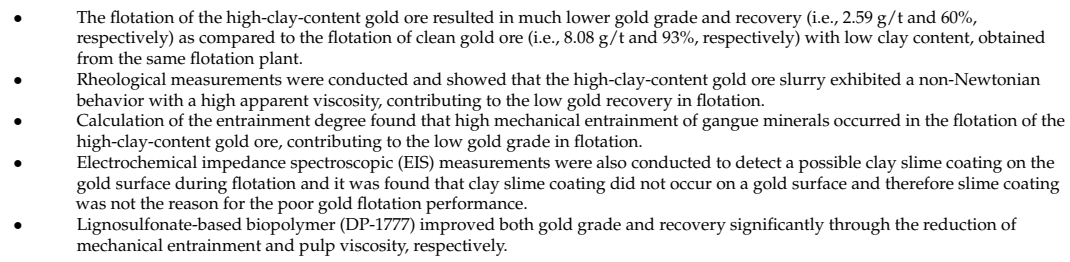 \\
\hline Li et al., 2020 [220] & N/A & $\begin{array}{l}\text { - To study the correlation between froth stability and viscosity, } \\
\text { experimentally. }\end{array}$ & 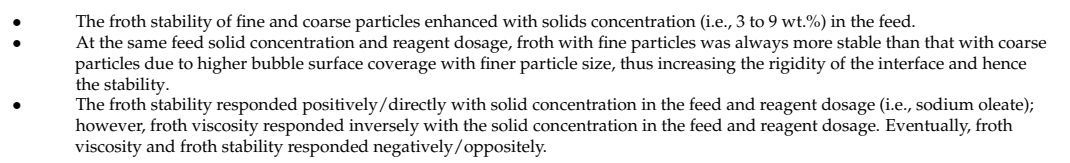 \\
\hline
\end{tabular}




\section{Summary and Future Perspectives}

In this review article, fine particle flotation along with the suspension rheological studies and their correlation was summarized and presented in order to obtain a better understanding of the complexities involved, as well as the challenges, and the current status. Low-grade and complex ores such as clayey and fibrous ores in large quantities are being processed but more viscous compared with conventional sulphide ores due to their depletion with high-grade ore worldwide. Therefore, rheology is an important property to understand and maintain the economic viability of the flotation process especially of low-grade and complex ores. Furthermore, several other physical, chemical, and mechanical parameters that affect the flotation performance of fine particles processing were discussed. From our literature review, a series of research gaps were identified, with the major identified gaps being a lack of (1) theoretical consideration in terms of the modeling of the correlation between the rheology and flotation, and (2) comprehension of the correlation between pulp and froth rheology possibly due to its complexity and/or lack of this perspective. These aspects are highly recommended for further study in the future.

Author Contributions: Conceptualization, M.S. and A.O.; methodology, M.S. and A.O.; software, M.S. and A.O.; validation, M.S. and A.O.; formal analysis, M.S. and A.O.; investigation, M.S. and A.O.; resources, M.S. and A.O.; data curation, M.S. and A.O.; writing-original draft preparation, M.S. and A.O.; writing - review and editing, M.S. and A.O.; visualization, M.S. and A.O.; supervision, A.O.; project administration, A.O.; funding acquisition, A.O. All authors have read and agreed to the published version of the manuscript.

Funding: The present work was partially supported by the European Union's Horizon 2020 research and innovation program under grant agreement No. 821265-FineFuture.

Data Availability Statement: Not applicable.

Conflicts of Interest: The authors declare no conflict of interest.

\section{Nomenclature}

$\begin{array}{ll}A_{H} & \text { Hamaker constant } \\ B_{0}^{*} & \text { Bond number } \\ d_{b} & \text { Bubble diameter } \\ \frac{d N_{p}}{d t} & \text { Rate of removal of particles by bubbles } \\ d_{p} & \text { Particle diameter } \\ d_{p b} & \frac{d_{p}+d_{b}}{2} \\ e & \text { Elementary charge } \\ E_{a} & \text { Attachment efficiency } \\ E_{c} & \text { Collision efficiency } \\ E_{c-s u} & \text { Sutherland collision efficiency } \\ e_{G} & \text { Entrainment factors for non-floatable minerals } \\ e_{M} & \text { Entrainment factors for floatable minerals } \\ E N T^{c o n: t a i l} & \text { Degree of entrainment } \\ E_{s} & \text { Stability efficiency } \\ f(t) & \text { Fraction of chalcopyrite remaining unrecovered after time t } \\ F_{E D L} & \text { Electrical double layer force } \\ F_{M} & \text { Intercept on the mineral recovery axis } \\ F_{V D W} & \text { Van der Waals force } \\ G_{f r} & \text { Gas flowrate } \\ H & \text { Inter-particle separation distance } \\ k & \text { Flotation rate constant } \\ k_{B} & \text { Boltzmann constant } \\ k_{f} & \text { Rate coefficient of the fast floating chalcopyrite } \\ k_{\text {max }} & \text { Maximum flotation rate constant } \\ k_{S} & \text { Rate coefficient of the slow floating chalcopyrite } \\ & \end{array}$




\begin{tabular}{|c|c|}
\hline$M_{\text {gangue }}$ & Mass of gangue minerals \\
\hline$M_{\text {water con }}$ & Mass of water in concentrate \\
\hline$M_{\text {water tail }}$ & Mass of water in tailings \\
\hline$n_{0}$ & Number concentration of ions \\
\hline$n_{B}$ & Bubble number concentration \\
\hline$n_{P}$ & Particle number concentration \\
\hline$N_{p}$ & Number density of particles \\
\hline$R \& R_{t}$ & Overall recovery of mineral (\%) \\
\hline$R_{\text {ent }}$ & Recovery by entrainment \\
\hline$R_{G}$ & Recoveries of non-floatable particles \\
\hline$R_{M}$ & Recoveries of floatable particles \\
\hline$R_{w}$ & Recovery of water in the cell (\%) \\
\hline$R_{\infty} \& R_{\max }$ & Flotation recovery at an infinite time \\
\hline$t$ & Time \\
\hline$T$ & Absolute temperature \\
\hline$v_{b}$ & Bubble velocity \\
\hline$V_{c e l}$ & Flotation cell volume \\
\hline$W_{\text {water }}$ & Weight of recovered water in given time \\
\hline$z$ & Ionic valence \\
\hline$Z_{B P}$ & Number of collisions per unit volume and time \\
\hline$\varepsilon$ & Dielectric constant \\
\hline$\epsilon$ & Turbulent dissipation energy \\
\hline$\varepsilon_{0}$ & Permittivity of free space \\
\hline$\kappa$ & Debye-Huckel reciprocal length \\
\hline$\eta$ & Fraction of non-floating chalcopyrite \\
\hline$\rho_{p}$ & Particle density \\
\hline$\rho_{f l}$ & Fluid density \\
\hline$\Delta \rho_{b}$ & $\rho_{p}-\rho_{f l}$ \\
\hline$v$ & Kinematic viscosity \\
\hline$v_{b}^{\prime}$ & Root-mean-square values of the turbulent velocity fluctuations of the bubble \\
\hline$v_{p}^{\prime}$ & Root-mean-square values of the turbulent velocity fluctuations of the particles \\
\hline$\tau_{y}$ & Shear yield stress \\
\hline$\tau_{\mathrm{y}(\max )}$ & Maximum shear yield stress \\
\hline$\varphi$ & Fraction of fast-floating chalcopyrite \\
\hline$\theta_{a}$ & Adhesion angle \\
\hline$\theta_{t}$ & Maximum possible collision angle of particle on bubble (angle of tangency) \\
\hline$\zeta$ & Zeta potential \\
\hline
\end{tabular}

\section{References}

1. Otsuki, A. Use of Microorganisms for Complex ORE Beneficiation: Bioflotation as an Example. In Encyclopedia of Biocolloid and Biointerface Science 2V Set; Wiley \& Sons: Hoboken, NJ, USA, 2016; pp. 108-117.

2. Otsuki, A.; Chen, Y.; Zhao, Y. Characterisation and Beneficiation of Complex Ores for Sustainable Use of Mineral Resources: Refractory Gold Ore Beneficiation as an Example. Int. J. Soc. Mater. Eng. Resour. 2014, 20, 126-135. [CrossRef]

3. Somasundaran, P.; Zhang, L.; Healy, T.; Ducker, W.; Herrera-Urbina, R.; Fuerstenau, M.C. Adsorption of Surfactants and Its Influence on the Hydrodynamics of Flotation. In Froth Flotation; A Century of Innovation; Fuerstenau, M.C., Jameson, G.J., Yoon, R., Eds.; Society for Mining, Metallurgy, and Exploration, Inc.: Littleton, CO, USA, 2007; pp. 179-225.

4. British Geological Survey; Bureau de Recherches Géologiques et Minières; Deloitte Sustainability; Directorate-General for Internal Market; Industry, Entrepreneurship and SMEs (European Commission); TNO. Study on the Review of the List of Critical Raw Materials; European Commission: Brussels, Belgium, 2017.

5. $\quad$ Blengini, G.A.; Latunussa, C.E.; Eynard, U.C.; Torres de Matos, D.; Wittmer, K.; Georgitzikis, C.; Pavel, S.; Carrara, L.; Mancini, M.; Unguru, D.; et al. Study on the EU's List of Critical Raw Materials; European Commission: Brussels, Belgium, 2020.

6. Dehaine, Q.; Filippov, L.O.; Filippova, I.V.; Tijsseling, L.T.; Glass, H.J. Novel approach for processing complex carbonate-rich copper-cobalt mixed ores via reverse flotation. Miner. Eng. 2021, 161, 106710. [CrossRef]

7. Zhang, S.; Yang, H.; Ma, P.; Luan, Z.; Tong, L.; Jin, Z.; Sand, W. Column bio-oxidation of low-grade refractory gold ore containing high-arsenic and high-sulfur: Insight on change in microbial community structure and sulfide surface corrosion. Miner. Eng. 2021, 175, 107201. [CrossRef]

8. $\quad$ Binnemans, K.; Jones, P.T.; Blanpain, B.; Van Gerven, T.; Pontikes, Y. Towards zero-waste valorisation of rare-earth-containing industrial process residues: A critical review. J. Clean. Prod. 2015, 99, 17-38. [CrossRef] 
9. Borra, C.R.; Blanpain, B.; Pontikes, Y.; Binnemans, K.; Van Gerven, T. Recovery of Rare Earths and Other Valuable Metals From Bauxite Residue (Red Mud): A Review. J. Sustain. Met. 2016, 2, 365-386. [CrossRef]

10. Edraki, M.; Baumgartl, T.; Manlapig, E.; Bradshaw, D.; Franks, D.; Moran, C.J. Designing mine tailings for better environmental, social and economic outcomes: A review of alternative approaches. J. Clean. Prod. 2014, 84, 411-420. [CrossRef]

11. Lèbre, É.; Corder, G.; Golev, A. The Role of the Mining Industry in a Circular Economy: A Framework for Resource Management at the Mine Site Level. J. Ind. Ecol. 2017, 21, 662-672. [CrossRef]

12. Otsuki, A.; Dodbiba, G.; Fujita, T. Two-Liquid Flotation: Heterocoagulation of Fine Particles in Polar Organic Solvent. Mater. Trans. 2007, 48, 1095-1104. [CrossRef]

13. Zhou, F.; Wang, L.; Xu, Z.; Liu, Q.; Chi, R. Reactive oily bubble technology for flotation of apatite, dolomite and quartz. Int. J. Miner. Process. 2015, 134, 74-81. [CrossRef]

14. Otsuki, A.; Miller, T. Experimental Investigation on Safer Frother Option for Coal Flotation. Curr. Work. Miner. Process. 2019, 1, 1-12. [CrossRef]

15. Yen, W.M.; Shionoya, S.; Yamamoto, H. Methods of phosphor synthesis and related technology. In Phosphor Handbook, 2nd ed.; Shionoya, S., Yen, W.M., Yamamoto, H., Eds.; CRC Press: Boca Raton, FL, USA, 2007; pp. 391-394.

16. Balaram, V. Rare earth elements: A review of applications, occurrence, exploration, analysis, recycling, and environmental impact. Geosci. Front. 2019, 10, 1285-1303. [CrossRef]

17. Ganguli, R.; Cook, D.R. Rare earths: A review of the landscape. MRS Energy Sustain. 2018, 5, 6. [CrossRef]

18. Peiró, L.T.; Méndez, G.V. Material and Energy Requirement for Rare Earth Production. JOM 2013, 65, 1327-1340. [CrossRef]

19. Zambrana, G.; Medina, R.; Gutierrez, G.; Vargas, R. Recovery of minus ten micron cassiterite by liquid-liquid extraction. Int. J. Miner. Process. 1974, 1, 335-345. [CrossRef]

20. Hu, B.; Nakahiro, Y.; Wakamatsu, T. The effect of organic solvents on the recovery of fine mineral particles by liquid-liquid extraction. Miner. Eng. 1993, 6, 731-742. [CrossRef]

21. Otsuki, A.; Mei, G.; Jiang, Y.; Matsuda, M.; Shibayama, A.; Sadaki, J.; Fujita, T. Solid-Solid Separation of Fluorescent Powders by Liquid-Liquid Extraction Using Aqueous and Organic Phases. Resour. Process. 2006, 53, 121-133. [CrossRef]

22. Otsuki, A.; Dodbiba, G.; Shibayama, A.; Sadaki, J.; Mei, G.; Fujita, T. Separation of Rare Earth Fluorescent Powders by Two-Liquid Flotation using Organic Solvents. Jpn. J. Appl. Phys. 2008, 47, 5093-5099. [CrossRef]

23. Ding, K.; Laskowski, J. Application of a Modified Water Glass in a Cationic Flotation of Calcite and Dolomite. Can. Metall. Q. 2006, 45, 199-206. [CrossRef]

24. Liu, Y.; Liu, Q. Flotation separation of carbonate from sulfide minerals, I: Flotation of single minerals and mineral mixtures. Miner. Eng. 2004, 17, 855-863. [CrossRef]

25. Luo, X.M.; Yin, W.Z.; Wang, Y.F.; Sun, C.-Y.; Ma, Y.Q.; Liu, J. Effect and mechanism of dolomite with different size fractions on hematite flotation using sodium oleate as collector. J. Central South Univ. 2016, 23, 529-534. [CrossRef]

26. Wonyen, D.G.; Kromah, V.; Gibson, B.; Nah, S.; Chelgani, S.C. A Review of Flotation Separation of Mg Carbonates (Dolomite and Magnesite). Minerals 2018, 8, 354. [CrossRef]

27. Ni, X.; Liu, Q. Adsorption behaviour of sodium hexametaphosphate on pyrochlore and calcite. Can. Met. Q. 2013, 52, 473-478. [CrossRef]

28. Luo, X.; Wang, Y.; Wen, S.; Ma, M.; Sun, C.; Yin, W.; Ma, Y. Effect of carbonate minerals on quartz flotation behavior under conditions of reverse anionic flotation of iron ores. Int. J. Miner. Process. 2016, 152, 1-6. [CrossRef]

29. Li, D.; Yin, W.-Z.; Xue, J.-W.; Yao, J.; Fu, Y.-F.; Liu, Q. Solution chemistry of carbonate minerals and its effects on the flotation of hematite with sodium oleate. Int. J. Miner. Met. Mater. 2017, 24, 736-744. [CrossRef]

30. World Coal Association. Coal Facts. Available online: https:/ /www.worldcoal.org/coal-facts/ (accessed on 26 June 2021).

31. Aaron, N.; Luttrell, G.H. A review of state-of-the-art processing operations in coal preparation. Int. J. Min. Sci. Technol. 2015, 25, 511-521. [CrossRef]

32. Lynch, A.; Johnson, N.; Manlapig, E.; Thorne, C. Mineral and Coal Flotation Circuits: Their Simulation and Control; Elsevier: Amsterdam, The Netherlands, 1980; p. 292.

33. Gaudin, A.; Flotation, M.; Fuerstenau, C. Flotation: A.M. Gaudin Memorial Volume; American Institute of Mining, Metallurgical, and Petroleum Engineers: New York, NY, USA, 1976; p. 1341.

34. Fornasiero, D.; Filippov, L.O. Innovations in the flotation of fine and coarse particles. J. Phys. Conf. Ser. 2017, 879, 12002. [CrossRef]

35. Miettinen, T.; Ralston, J.; Fornasiero, D. The limits of fine particle flotation. Miner. Eng. 2010, 23, 420-437. [CrossRef]

36. Otsuki, A.; Yue, C. Coal-oil gold agglomeration assisted flotation to recover gold from refractory ore. J. Phys. Conf. Ser. 2017, 879, 012021. [CrossRef]

37. Farrokhpay, S.; Filippov, L.; Fornasiero, D. Flotation of Fine Particles: A Review. Miner. Process. Extr. Met. Rev. 2021, $42,473-483$. [CrossRef]

38. Ansari, M. Fine Particle Processing-A Difficult Problem for Mining Engineers. 1997. Available online: https://eprints.nmlindia. org /2867/ (accessed on 26 June 2021).

39. Nguyen, A.; Kmet, S. Probability of collision between particles and bubbles in flotation: The theoretical inertialess model involving a swarm of bubbles in pulp phase. Int. J. Miner. Process. 1994, 40, 155-169. [CrossRef]

40. Shahbazi, B.; Rezai, B.; Koleini, S.J. Bubble-particle collision and attachment probability on fine particles flotation. Chem. Eng. Process. Process Intensif. 2010, 49, 622-627. [CrossRef] 
41. Wang, L.; Peng, Y.; Runge, K. Entrainment in froth flotation: The degree of entrainment and its contributing factors. Powder Technol. 2016, 288, 202-211. [CrossRef]

42. Smith, P.G.; Warren, L.J. Entrainment of Particles into Flotation Froths. Miner. Process. Extr. Met. Rev. 1989, 5, 123-145. [CrossRef]

43. Ahmed, N.; Jameson, G. The effect of bubble size on the rate of flotation of fine particles. Int. J. Miner. Process. 1985, 14, 195-215. [CrossRef]

44. Yoon, R.H.; Luttrell, G.H. The Effect of Bubble Size on Fine Particle Flotation. Miner. Process. Extr. Met. Rev. 1989, 5, 101-122. [CrossRef]

45. Hu, Y.; Qiu, G.; Miller, J. Hydrodynamic interactions between particles in aggregation and flotation. Int. J. Miner. Process. 2003, 70, 157-170. [CrossRef]

46. Farrokhpay, S. The importance of rheology in mineral flotation: A review. Miner. Eng. 2012, 36-38, 272-278. [CrossRef]

47. Boger, D.V. Rheology and the Resource Industries. In Proceedings of the 14th Asia Pacific Confederation of Chemical Engineering Congress, Singapore, 22-24 February 2012; Volume 64, pp. 4525-4536. [CrossRef]

48. Orlich, J.N.; Iwasaki, I. Effects of slurry rheology and ball coating on abrasive wear and the grinding rate of quartzite. Min. Met. Explor. 1987, 4, 32-37. [CrossRef]

49. Bazin, C.; Obiang, P. Should the slurry density in a grinding mill be adjusted as a function of grinding media size? Miner. Eng. 2007, 20, 810-815. [CrossRef]

50. Govender, I.; Tupper, G.; Mainza, A. Towards a mechanistic model for slurry transport in tumbling mills. Miner. Eng. 2011, 24, 230-235. [CrossRef]

51. Bazin, C.; B-Chapleau, C. The difficulty associated with measuring slurry rheological properties and linking them to grinding mill performance. Int. J. Miner. Process. 2005, 76, 93-99. [CrossRef]

52. Tavares, L.; Souza, L.; Lima, J.; Possa, M. Modeling classification in small-diameter hydrocyclones under variable rheological conditions. Miner. Eng. 2002, 15, 613-622. [CrossRef]

53. Possa, M.; Lima, J. The effect of viscosity on small-diameter hydrocyclones' performance in desliming process. Develop. Miner. Process. 2000, 13, C4-29-C4-35. [CrossRef]

54. Marthinussen, S.-A.; Chang, Y.-F.; Balakin, B.; Hoffmann, A.C. Removal of particles from highly viscous liquids with hydrocyclones. Chem. Eng. Sci. 2014, 108, 169-175. [CrossRef]

55. Doby, M.J.; Nowakowski, A.F.; Yiu, I.; Dyakowski, T. Understanding air core formation in hydrocyclones by studying pressure distribution as a function of viscosity. Int. J. Miner. Process. 2008, 86, 18-25. [CrossRef]

56. Cruz, N.; Peng, Y.; Wightman, E.; Xu, N. The interaction of $\mathrm{pH}$ modifiers with kaolinite in copper-gold flotation. Miner. Eng. 2015, 84, 27-33. [CrossRef]

57. Forbes, E.; Davey, K.; Smith, L. Decoupling rehology and slime coatings effect on the natural flotability of chalcopyrite in a clay-rich flotation pulp. Miner. Eng. 2014, 56, 136-144. [CrossRef]

58. Shi, F.; Zheng, X. The rheology of flotation froths. Int. J. Miner. Process. 2003, 69, 115-128. [CrossRef]

59. Jeldres, R.I.; Uribe, L.; Cisternas, L.A.; Gutierrez, L.; Leiva, W.H.; Valenzuela, J. The effect of clay minerals on the process of flotation of copper ores-A critical review. Appl. Clay Sci. 2019, 170, 57-69. [CrossRef]

60. Subrahmanyam, T.; Forssberg, E. Froth stability, particle entrainment and drainage in flotation-A review. Int. J. Miner. Process. 1988, 23, 33-53. [CrossRef]

61. Cruz, N.; Forster, J.; Bobicki, E.R. Slurry rheology in mineral processing unit operations: A critical review. Can. J. Chem. Eng. 2019, 97, 2102-2120. [CrossRef]

62. Wang, L.; Li, C. A Brief Review of Pulp and Froth Rheology in Mineral Flotation. J. Chem. 2020, 2020, 1-16. [CrossRef]

63. Blair, C.C.; Brian, Q. Microplastic separation techniques. In Microplastic Pollutants; Elsevier: Amsterdam, The Netherlands, 2017; pp. 203-218.

64. Otsuki, A.; Zhao, Y. UV-Vis Study of Mixed Collector Adsorption on Pyrite to enhance refractory gold ore beneficiation by flotation. Curr. Work. Miner. Process. 2018, 1, 13-20.

65. Otsuki, A.; Miller, T. Safer Frother Option for Coal Flotation-A Review. Curr. Work. Miner. Process. 2019, 1, 21-29. [CrossRef]

66. Crabtree, E.; Vincent, J. Historical Outline of Major Flotation Developments. In Froth Flotation; Anniversary Volume; Fuerstenau, D.W., Ed.; AIME: New York, NY, USA, 1962; Volume 50, pp. 39-54.

67. Fuerstenau, M.; Sabacky, B. On the natural floatability of sulfides. Int. J. Miner. Process. 1981, 8, 79-84. [CrossRef]

68. Wills, B.A.; Finch, J.A. Wills' Mineral Processing Technology: An Introduction to the Practical Aspects of Ore Treatment and Mineral Recovery, 8th ed.; Butterworth-Heinemann: Oxford, UK, 2016; 512p.

69. Tymon. Lin Ma Hang Mine Part 3-Exploitation. The Industrial History of Hong Kong Group. 28 April 2018. Available online: https:/ /industrialhistoryhk.org/lin-ma-hang-part-3-exploitation/ (accessed on 25 January 2021).

70. Wu, Z.H.; Hu, Y.J.; Lee, D.J.; Mujumdar, A.S.; Li, Z.Y. Dewatering and Drying in Mineral Processing Industry: Potential for Innovation. Dry. Technol. 2010, 28, 834-842. [CrossRef]

71. Le Roux, M.; Campbell, Q.; Watermeyer, M.; de Oliveira, S. The optimization of an improved method of fine coal dewatering Miner. Eng. 2005, 18, 931-934. [CrossRef]

72. Kelly, E.G. Mineral Processing. In Encyclopedia of Physical Science and Technology, 3rd ed.; Meyers, R.A., Ed.; Academic Press: Cambridge, MA, USA, 2003; pp. 29-57. 
73. Kyzas, G.Z.; Lazaridis, N.; Matis, K.A. Flotation: Recent innovations in an interesting and effective separation process. In Interface Science and Technology; Kyzas, G.Z., Mitropoulos, A.C., Eds.; Elsevier: Amsterdam, The Netherlands, 2019; Volume 30, pp. 15-42.

74. Li, S.; Lu, D.; Chen, X.; Zheng, X.; Li, X.; Chu, H.; Wang, Y. Industrial application of a modified pilot-scale Jameson cell for the flotation of spodumene ore in high altitude area. Powder Technol. 2017, 320, 358-361. [CrossRef]

75. Nakhaei, F.; Mosavi, M.R.; Sam, A.; Vaghei, Y. Recovery and grade accurate prediction of pilot plant flotation column concentrate: Neural network and statistical techniques. Int. J. Miner. Process. 2012, 110-111, 140-154. [CrossRef]

76. Goodall, C.; O'Connor, C. Pulp-froth interactions in a laboratory column flotation cell. Miner. Eng. 1991, 4, 951-958. [CrossRef]

77. Vashisth, S.; Bennington, C.P.; Grace, J.R.; Kerekes, R.J. Column Flotation Deinking: State-of-the-art and opportunities. Resour. Conserv. Recycl. 2011, 55, 1154-1177. [CrossRef]

78. Anderson, C.; Harris, M.; Deglon, D. Flotation in a novel oscillatory baffled column. Miner. Eng. 2009, 22, 1079-1087. [CrossRef]

79. Finch, J. Column flotation: A selected review_ part IV: Novel flotation devices. Miner. Eng. 1995, 8, 587-602. [CrossRef]

80. Gu, L.; Yalcin, T. Semi-batch flotation column. Miner. Eng. 2011, 26, 105-107. [CrossRef]

81. Tao, D.; Luttrell, G.; Yoon, R.-H. An experimental investigation on column flotation circuit configuration. Int. J. Miner. Process. 2000, 60, 37-56. [CrossRef]

82. Samygin, V.D.; Panin, V.V.; Filippov, L.; Stenin, N.Y. Development of a reactor-separator flotation machine designed by the Moscow Institute of Steel and Alloys. Metals 2010, 54, 394-400. [CrossRef]

83. Fuerstenau, D. Fine particle flotation. In Proceedings of the International Symposium, Freiburg, Germany, 27-31 May 1980.

84. Li, H. The Roles of Non-Polar Oil in Froth Flotation of Fine Particles. Ph.D. Thesis, University of Alberta, Edmonton, AB, Canada, 2018.

85. Hiemenz, P.C.; Rajagopalan, R. Principles of Colloid and Surface Chemistry; Marcel Dekker: New York, NY, USA, 1997.

86. Fornasiero, D.; Ralston, J. Cu(II) and Ni(II) activation in the flotation of quartz, lizardite and chlorite. Int. J. Miner. Process. 2005, 76, 75-81. [CrossRef]

87. Zhou, Z.; Scales, P.; Boger, D.V. Chemical and physical control of the rheology of concentrated metal oxide suspensions. Chem. Eng. Sci. 2001, 56, 2901-2920. [CrossRef]

88. Qin, K.; Zaman, A.A. Viscosity of concentrated colloidal suspensions: Comparison of bidisperse models. J. Colloid Interface Sci. 2003, 266, 461-467. [CrossRef]

89. Genovese, D.B. Shear rheology of hard-sphere, dispersed, and aggregated suspensions, and filler-matrix composites. Adv. Colloid Interface Sci. 2012, 171-172, 1-16. [CrossRef]

90. Russel, W.B. Review of the Role of Colloidal Forces in the Rheology of Suspensions. J. Rheol. 1980, 24, 287-317. [CrossRef]

91. Metzner, A.B. Rheology of Suspensions in Polymeric Liquids. J. Rheol. 1985, 29, 739-775. [CrossRef]

92. Servais, C.; Jones, R.; Roberts, I. The influence of particle size distribution on the processing of food. J. Food Eng. 2002, 51, 201-208. [CrossRef]

93. Shengo, M.; Kime, M.-B.; Mambwe, M.; Nyembo, T. A review of the beneficiation of copper-cobalt-bearing minerals in the Democratic Republic of Congo. J. Sustain. Min. 2019, 18, 226-246. [CrossRef]

94. Benzaazoua, M.; Bussière, B.; Kongolo, M.; McLaughlin, J.; Marion, P. Environmental desulphurization of four Canadian mine tailings using froth flotation. Int. J. Miner. Process. 2000, 60, 57-74. [CrossRef]

95. Mbamba, C.K.; Harrison, S.; Franzidis, J.-P.; Broadhurst, J. Mitigating acid rock drainage risks while recovering low-sulfur coal from ultrafine colliery wastes using froth flotation. Miner. Eng. 2012, 29, 13-21. [CrossRef]

96. Stankovic, V.; Milosevic, V.; Milicevic, D.; Gorgievski, M.; Bogdanovic, G. Reprocessing of the old flotation tailings deposited on the RTB Bor tailings pond-A case study. Chem. Ind. Chem. Eng. Q. 2018, 24, 333-344. [CrossRef]

97. Chen, D.; Yu, Y.; Liu, L.M.; Bin Han, Z. Study on Flotation Technique to Recycle Copper from Tailings. Adv. Mater. Res. 2014, 878, 322-329. [CrossRef]

98. Darabi, H.; Koleini, S.J.; Deglon, D.; Rezai, B.; Abdollahy, M. Investigation of bubble-particle interactions in a mechanical flotation cell, part 1: Collision frequencies and efficiencies. Miner. Eng. 2019, 134, 54-64. [CrossRef]

99. Dai, Z.; Fornasiero, D.; Ralston, J. Particle-bubble collision models-A review. Adv. Colloid Interface Sci. 2000, 85, 231-256. [CrossRef]

100. Ralston, J.; Fornasiero, D.; Hayes, R. Bubble-particle attachment and detachment in flotation. Int. J. Miner. Process. 1999, 56, 133-164. [CrossRef]

101. Darabi, H.; Koleini, S.J.; Deglon, D.; Rezai, B.; Abdollahy, M. Investigation of bubble-particle attachment, detachment and collection efficiencies in a mechanical flotation cell. Powder Technol. 2020, 375, 109-123. [CrossRef]

102. Derjaguin, B.; Dukhin, S. Theory of flotation of small and medium-size particles. Prog. Surf. Sci. 1993, 43, 241-266. [CrossRef]

103. Pyke, B.; Fornasiero, D.; Ralston, J. Bubble particle heterocoagulation under turbulent conditions. J. Colloid Interface Sci. 2003, 265, 141-151. [CrossRef]

104. Trahar, W.; Warren, L. The flotability of very fine particles-A review. Int. J. Miner. Process. 1976, 3, 103-131. [CrossRef]

105. Hassanzadeh, A.; Hassas, B.V.; Kouachi, S.; Brabcova, Z.; Çelik, M.S. Effect of bubble size and velocity on collision efficiency in chalcopyrite flotation. Colloids Surfaces A Physicochem. Eng. Asp. 2016, 498, 258-267. [CrossRef]

106. Yoon, R.H.; Luttrell, G.H. The Effect of Bubble Size on Fine Coal Flotation. Coal Prep. 1986, 2, 179-192. [CrossRef]

107. Dai, Z.; Fornasiero, D.; Ralston, J. Influence of dissolved gas on bubble-particle heterocoagulation. J. Chem. Soc. Faraday Trans. 1998, 94, 1983-1987. [CrossRef] 
108. Reay, D.; Ratcliff, G.A. Experimental testing of the hydrodynamic collision model of fine particle flotation. Can. J. Chem. Eng. 1975, 53, 481-486. [CrossRef]

109. Liu, Q.; Wannas, D. The Role of Polymeric-depressant-induced Flocculation in Fine Particle Flotation. In Proceedings of the Fifth UBC-McGill Biennial International Symposium on Fundamentals of Mineral, 43rd Annual Conference of Metallurgists of CIM, Montreal, QC, Canada, 22-25 August 2004.

110. Schwarz, S.; Grano, S. Effect of particle hydrophobicity on particle and water transport across a flotation froth. Colloids Surfaces A Physicochem. Eng. Asp. 2005, 256, 157-164. [CrossRef]

111. Li, H.; Liu, M.; Liu, Q. Oil-assisted flotation of fine hematite using sodium oleate or hydroxamic acids as a collector. Physicochem. Probl. Miner. Processing 2018, 54, 1130-1145.

112. Song, S.; Lopez-Valdivieso, A. Parametric aspect of Hydrophobic flocculation technology. Miner. Process. Extr. Met. Rev. 2002, 23, 101-127. [CrossRef]

113. Cadzow, M.D.; Elkes, G.J.; Ewin, G.J.; Mainwaring, D.E. Recovery of Metal Values from Mineral Ores by Incorporation in Coal-Oil Agglomerates. U.S. Patent 4,585,548, 29 April 1986.

114. Şen, Ş.; Seyrankaya, A.; Cilingir, Y. Coal-oil assisted flotation for the gold recovery. Miner. Eng. 2005, 18, 1086-1092. [CrossRef]

115. Akcil, A.; Wu, X.Q.; Aksay, E.K. Coal-Gold Agglomeration: An Alternative Separation Process in Gold Recovery. Sep. Purif. Rev. 2009, 38, 173-201. [CrossRef]

116. Zou, S.; Ma, X.; Wang, S.; Zhong, H.; Qin, W. Flotation of rhodochrosite fines induced by octyl hydroxamic acid as hydrophobic agglomerates. Powder Technol. 2021, 392, 108-115. [CrossRef]

117. Song, S.; Lopez-Valdivieso, A.; Reyes-Bahena, J.L.; Bermejo-Perez, H.I.; Trass, O. Hydrophobic Flocculation of Galena Fines in Aqueous Suspensions. J. Colloid Interface Sci. 2000, 227, 272-281. [CrossRef]

118. Yin, W.-Z.; Yang, X.-S.; Zhou, D.-P.; Li, Y.-J.; Lü, Z.-F. Shear hydrophobic flocculation and flotation of ultrafine Anshan hematite using sodium oleate. Trans. Nonferrous Met. Soc. China 2011, 21, 652-664. [CrossRef]

119. Duan, J.; Fornasiero, D.; Ralston, J. Calculation of the flotation rate constant of chalcopyrite particles in an ore. Int. J. Miner. Process. 2003, 72, 227-237. [CrossRef]

120. Song, S.; Lopez-Valdivieso, A.; Reyes-Bahena, J.L.; Lara-Valenzuela, C. Floc flotation of galena and sphalerite fines. Miner. Eng. 2001, 14, 87-98. [CrossRef]

121. Hewitt, D.; Fornasiero, D.; Ralston, J. Bubble-particle attachment. J. Chem. Soc. Faraday Trans. 1995, 91, 1997-2001. [CrossRef]

122. Rubio, J.; Capponi, F.; Rodrigues, R.; Matiolo, E. Enhanced flotation of sulfide fines using the emulsified oil extender technique. Int. J. Miner. Process. 2007, 84, 41-50. [CrossRef]

123. Arriagada, S.; Acuña, C.; Vera, M. New technology to improve the recovery of fine particles in froth flotation based on using hydrophobized glass bubbles. Miner. Eng. 2020, 156, 106364. [CrossRef]

124. Farrokhpay, S.; Filippova, I.; Filippov, L.; Picarra, A.; Rulyov, N.; Fornasiero, D. Flotation of fine particles in the presence of combined microbubbles and conventional bubbles. Miner. Eng. 2020, 155, 106439. [CrossRef]

125. Zhou, S.; Wang, X.; Bu, X.; Wang, M.; An, B.; Shao, H.; Ni, C.; Peng, Y.; Xie, G. A novel flotation technique combining carrier flotation and cavitation bubbles to enhance separation efficiency of ultra-fine particles. Ultrason. Sonochem. 2020, $64,105005$. [CrossRef]

126. Zhang, Z.; Ren, L.; Zhang, Y. Role of nanobubbles in the flotation of fine rutile particles. Miner. Eng. 2021, 172, 107140. [CrossRef]

127. Gontijo, C.D.F.; Fornasiero, D.; Ralston, J. The Limits of Fine and Coarse Particle Flotation. Can. J. Chem. Eng. 2008, 85, 739-747. [CrossRef]

128. Sutherland, K.L. Physical Chemistry of Flotation. XI. Kinetics of the Flotation Process. J. Phys. Chem. 1948, 52, 394-425. [CrossRef]

129. Hassanzadeh, A.; Firouzi, M.; Albijanic, B.; Celik, M.S. A review on determination of particle-bubble encounter using analytical, experimental and numerical methods. Miner. Eng. 2018, 122, 296-311. [CrossRef]

130. Pease, J.; Curry, D.; Young, M. Designing flotation circuits for high fines recovery. Miner. Eng. 2006, 19, 831-840. [CrossRef]

131. Trahar, W. A rational interpretation of the role of particle size in flotation. Int. J. Miner. Process. 1981, 8, 289-327. [CrossRef]

132. Warren, L.J. Determination of the contributions of true flotation and entrainment in batch flotation tests. Int. J. Miner. Process. 1985, 14, 33-44. [CrossRef]

133. Mhonde, N.; Wiese, J.; McFadzean, B. Comparison of collector performance for a South African and a Brazilian iron ore considering mineralogical characteristics. Miner. Eng. 2017, 113, 55-67. [CrossRef]

134. Wang, D.; Liu, Q. Influence of aggregation/dispersion state of hydrophilic particles on their entrainment in fine mineral particle flotation. Miner. Eng. 2021, 166, 106835. [CrossRef]

135. George, P.; Nguyen, A.; Jameson, G. Assessment of true flotation and entrainment in the flotation of submicron particles by fine bubbles. Miner. Eng. 2004, 17, 847-853. [CrossRef]

136. Innocent Achaye. Effect of Particle Properties on Froth Stability; University of Cape Town: Cape Town, South Africa, 2017.

137. Barbian, N.; Ventura-Medina, E.; Cilliers, J. Mineral Attachment and Bubble Bursting in Flotation Froths; Australasian Institute of Mining and Metallurgy: Carlton, VA, Australia, 2005; pp. 321-327.

138. Aktas, Z.; Cilliers, J.; Banford, A. Dynamic froth stability: Particle size, airflow rate and conditioning time effects. Int. J. Miner. Process. 2008, 87, 65-71. [CrossRef]

139. Pugh, R. Experimental techniques for studying the structure of foams and froths. Adv. Colloid Interface Sci. 2005, 114-115, 239-251. [CrossRef] [PubMed] 
140. Tang, F.-Q.; Xiao, Z.; Tang, J.-A.; Jiang, L. The effect of SiO2 particles upon stabilization of foam. J. Colloid Interface Sci. 1989, 131, 498-502. [CrossRef]

141. Arnold, B.; Aplan, F. The effect of clay slimes on coal flotation, part I: The nature of the clay. Int. J. Miner. Process. 1986, 17, 225-242. [CrossRef]

142. Taggart, A.; Taylor, T.; Ince, C. Experiments with Flotation Agents; The American Institute of Mining, Metallurgical, and Petroleum Engineers: New York, NY, USA, 1929; Volume 87, pp. 285-386.

143. Attia, Y.A.; Deason, D. Control of slimes coating in mineral suspensions. Colloids Surfaces 1989, 39, 227-238. [CrossRef]

144. Oats, W.J.; Ozdemir, O.; Nguyen, A. Effect of mechanical and chemical clay removals by hydrocyclone and dispersants on coal flotation. Miner. Eng. 2010, 23, 413-419. [CrossRef]

145. Bakker, C.; Meyer, C.; Deglon, D. The development of a cavern model for mechanical flotation cells. Miner. Eng. 2010, 23, 968-972. [CrossRef]

146. Farrokhpay, S. The significance of froth stability in mineral flotation-A review. Adv. Colloid Interface Sci. 2011, 166, 1-7. [CrossRef]

147. Ndlovu, B.; Becker, M.; Forbes, E.; Deglon, D.; Franzidis, J.-P. The influence of phyllosilicate mineralogy on the rheology of mineral slurries. Miner. Eng. 2011, 24, 1314-1322. [CrossRef]

148. Shabalala, N.; Harris, M.; Filho, L.L.; Deglon, D. Effect of slurry rheology on gas dispersion in a pilot-scale mechanical flotation cell. Miner. Eng. 2011, 24, 1448-1453. [CrossRef]

149. Patra, P.; Bhambhani, T.; Nagaraj, D.; Somasundaran, P. Impact of pulp rheological behavior on selective separation of Ni minerals from fibrous serpentine ores. Colloids Surfaces A Physicochem. Eng. Asp. 2012, 411, 24-26. [CrossRef]

150. Wang, L.; Runge, K.; Peng, Y.; Vos, C. An empirical model for the degree of entrainment in froth flotation based on particle size and density. Miner. Eng. 2016, 98, 187-193. [CrossRef]

151. Forrest, W.R.; Adel, G.T.; Yoon, R.-H. Characterizing Coal Flotation Performance Using Release Analysis. Coal Prep. 1994, 14, 13-27. [CrossRef]

152. Akdemir, Ü.; Sönmez, I. Investigation of coal and ash recovery and entrainment in flotation. Fuel Process. Technol. 2003, 82, 1-9. [CrossRef]

153. Wang, L.; Peng, Y.; Runge, K.; Bradshaw, D. A review of entrainment: Mechanisms, contributing factors and modelling in flotation. Miner. Eng. 2015, 70, 77-91. [CrossRef]

154. Malkin, A.Y.; Isayev, A.I. Introduction. Rheology; Subject and Goals. In Rheology. Concepts, Methods, and Applications, 3rd ed.; Elsevier: London, UK, 2017; pp. 1-8.

155. Taylor, M.L.; Morris, G.E.; Smart, R.S. Influence of aluminum doping on titania pigment structural and dispersion properties. J. Colloid Interface Sci. 2003, 262, 81-88. [CrossRef]

156. Farrokhpay, S.; Morris, G.E.; Fornasiero, D.; Self, P. Stabilisation of titania pigment particles with anionic polymeric dispersants. Powder Technol. 2010, 202, 143-150. [CrossRef]

157. Mpofu, P.; Addai-Mensah, J.; Ralston, J. Investigation of the effect of polymer structure type on flocculation, rheology and dewatering behaviour of kaolinite dispersions. Int. J. Miner. Process. 2003, 71, 247-268. [CrossRef]

158. McFarlane, A.; Bremmell, K.; Addai-Mensah, J. Microstructure, rheology and dewatering behaviour of smectite dispersions during orthokinetic flocculation. Miner. Eng. 2005, 18, 1173-1182. [CrossRef]

159. Nosrati, A.; Addai-Mensah, J.; Skinner, W. Rheology of aging aqueous muscovite clay dispersions. Chem. Eng. Sci. 2011, 66, 119-127. [CrossRef]

160. Morris, E.G.; Fornasiero, D.; Ralston, J. Polymer depressants at the talc-water interface: Adsorption isotherm, microflotation and electrokinetic studies. Int. J. Miner. Process. 2002, 67, 211-227. [CrossRef]

161. Burdukova, E.; Bradshaw, D.; Laskowski, J. Effect of CMC and pH on the Rheology of Suspensions of Isotropic and Anisotropic Minerals. Can. Met. Q. 2007, 46, 273-278. [CrossRef]

162. Dinçer, H.; Boylu, F.; Sirkeci, A.; Ateşok, G. The effect of chemicals on the viscosity and stability of coal water slurries. Int. J. Miner. Process. 2003, 70, 41-51. [CrossRef]

163. Muster, T.; Prestidge, C. Rheological investigations of sulphide mineral slurries. Miner. Eng. 1995, 8, 1541-1555. [CrossRef]

164. Clout, J.; Manuel, J. Mineralogical, chemical, and physical characteristics of iron ore. In Iron Ore; Elsevier BV: Amsterdam, The Netherlands, 2015; pp. 45-84.

165. Paar, A. Viscosity and Viscometry. Available online: https://wiki.anton-paar.com/en/basic-of-viscometry/\#apparent-viscosity (accessed on 24 June 2021).

166. Otsuki, A. Rheology of colloidal particle suspensions. In Micro and Nano Technologies, Rheology of Polymer Blends and Nanocomposites; Thomas, S., Sarathchandran, C., Chandran, N., Eds.; Elsevier: Amsterdam, The Netherlands, 2020; pp. 49-71.

167. Ndlovu, B.; Forbes, E.; Farrokhpay, S.; Becker, M.; Bradshaw, D.; Deglon, D. A preliminary rheological classification of phyllosilicate group minerals. Miner. Eng. 2014, 55, 190-200. [CrossRef]

168. Otsuki, A.; Bryant, G. Characterization of the interactions within fine particle mixtures in highly concentrated suspensions for advanced particle processing. Adv. Colloid Interface Sci. 2015, 226, 37-43. [CrossRef]

169. Nguyen, A.; George, P.; Jameson, G.J. Demonstration of a minimum in the recovery of nanoparticles by flotation: Theory and experiment. Chem. Eng. Sci. 2006, 61, 2494-2509. [CrossRef]

170. Ata, S.; Yates, P. Stability and flotation behaviour of silica in the presence of a non-polar oil and cationic surfactant. Colloids Surfaces A Physicochem. Eng. Asp. 2006, 277, 1-7. [CrossRef] 
171. Kusaka, E.; Tamai, H.; Nakahiro, Y.; Wakamatsu, T. Role of surface free energy in a solid surface during collectorless liquid-liquid extraction. Miner. Eng. 1993, 6, 455-464. [CrossRef]

172. Mitchell, T.K.; Nguyen, A.; Evans, G.M. Heterocoagulation of chalcopyrite and pyrite minerals in flotation separation. Adv. Colloid Interface Sci. 2005, 114-115, 227-237. [CrossRef] [PubMed]

173. Butt, H.-J.; Cappella, B.; Kappl, M. Force measurements with the atomic force microscope: Technique, interpretation and applications. Surf. Sci. Rep. 2005, 59, 1-152. [CrossRef]

174. Drelich, J.; Long, J.; Xu, Z.; Masliyah, J.; White, C. Probing colloidal forces between a Si3N4 AFM tip and single nanoparticles of silica and alumina. J. Colloid Interface Sci. 2006, 303, 627-638. [CrossRef]

175. Yoon, R.-H.; Flinn, D.H.; Rabinovich, Y.I. Hydrophobic Interactions between Dissimilar Surfaces. J. Colloid Interface Sci. 1997, 185, 363-370. [CrossRef]

176. Yates, P.D.; Franks, G.V.; Biggs, S.; Jameson, G.J. Heteroaggregation with nanoparticles: Effect of particle size ratio on optimum particle dose. Colloids Surfaces A Physicochem. Eng. Asp. 2005, 255, 85-90. [CrossRef]

177. Otsuki, A.; De Campo, L.; Garvey, C.J.; Rehm, C. H2O/D2O Contrast Variation for Ultra-Small-Angle Neutron Scattering to Minimize Multiple Scattering Effects of Colloidal Particle Suspensions. Colloids Interfaces 2018, 2, 37. [CrossRef]

178. Tamai, H.; Hakozaki, T.; Suzawa, T. Deposition of polymethyl methacrylate latex on fibers. Colloid Polym. Sci. 1980, 258, 870-876. [CrossRef]

179. Fujita, Y.; Kobayashi, M. The Initial Deposition Behavior of Silica Colloid and Amino-Modified Silica Colloid in Unsaturated Sand Columns. Water 2020, 12, 2892. [CrossRef]

180. Shiratori, K.; Yamashita, Y.; Adachi, Y. Deposition and subsequent release of Na-kaolinite particles by adjusting pH in the column packed with Toyoura sand. Colloids Surfaces A Physicochem. Eng. Asp. 2007, 306, 137-141. [CrossRef]

181. Hunter, R.J. Foundations of Colloids Science; Oxford University Press: Oxford, UK, 2001; pp. 749-760.

182. Addai-Mensah, J.; Ralston, J. Investigation of the role of interfacial chemistry on particle interactions, sedimentation and electroosmotic dewatering of model kaolinite dispersions. Powder Technol. 2005, 160, 35-39. [CrossRef]

183. Otsuki, A.; Barry, S.; Fornasiero, D. Rheological studies of nickel oxide and quartz/hematite mixture systems. Adv. Powder Technol. 2011, 22, 471-475. [CrossRef]

184. Mesa, D.; Brito-Parada, P.R. Scale-up in froth flotation: A state-of-the-art review. Sep. Purif. Technol. 2019, 210, 950-962. [CrossRef]

185. Deglon, D. The effect of agitation on the flotation of platinum ores. Miner. Eng. 2005, 18, 839-844. [CrossRef]

186. Schubert, H.; Bischofberger, C. On the hydrodynamics of flotation machines. Int. J. Miner. Process. 1978, 5, 131-142. [CrossRef]

187. Schubert, H.; Bischofberger, C. On the microprocesses air dispersion and particle-bubble attachment in flotation machines as well as consequences for the scale-up of macroprocesses. Int. J. Miner. Process. 1998, 52, 245-259. [CrossRef]

188. Sajjad, M.; Otsuki, A. Coupling flotation rate constant and viscosity models. Metals 2021, under review.

189. Ogawa, A.; Yamada, H.; Matsuda, S.; Okajima, K.; Doi, M. Viscosity equation for concentrated suspensions of charged colloidal particles. J. Rheol. 1997, 41, 769-785. [CrossRef]

190. Becker, M.; Yorath, G.; Ndlovu, B.; Harris, M.; Deglon, D.; Franzidis, J.-P. A rheological investigation of the behaviour of two Southern African platinum ores. Miner. Eng. 2013, 49, 92-97. [CrossRef]

191. Farrokhpay, S.; Ndlovu, B.; Bradshaw, D. Behaviour of swelling clays versus non-swelling clays in flotation. Miner. Eng. 2016, 96-97, 59-66. [CrossRef]

192. Chen, X.; Hadde, E.; Liu, S.; Peng, Y. The effect of amorphous silica on pulp rheology and copper flotation. Miner. Eng. 2017, 113, 41-46. [CrossRef]

193. Gibson, C.; Kelebek, S. Sensitivity of pentlandite flotation in complex sulfide ores towards $\mathrm{pH}$ control by lime versus soda ash: Effect on ore type. Int. J. Miner. Process. 2014, 127, 44-51. [CrossRef]

194. Michaud, D. The Importance of pH in Flotation. 911 Metallurgist. 10 August 2015. Available online: https://www.911metallurgist. $\mathrm{com} / \mathrm{blog} /$ the-importance-of-ph-control-in-flotation (accessed on 29 October 2021).

195. Sasaki, K.; Takatsugi, K.; Ishikura, K.; Hirajima, T. Spectroscopic study on oxidative dissolution of chalcopyrite, enargite and tennantite at different $\mathrm{pH}$ values. Hydrometallurgy 2010, 100, 144-151. [CrossRef]

196. Göktepe, F. Effect of $\mathrm{pH}$ on pulp potential and sulphide mineral flotation. Turk. J. Eng. Environ. Sci. 2002, 26, 309-318.

197. Anovitz, L.M.; Cole, D.R. Characterization and Analysis of Porosity and Pore Structures. Rev. Miner. Geochem. 2015, 80, 61-164. [CrossRef]

198. Bhattacharjee, S. DLS and zeta potential-What they are and what they are not? J. Control. Release 2016, 235, 337-351. [CrossRef]

199. Fuerstenau, M.C.; Miller, J.D.; Kuhn, M.C. Chemistry of Flotation; Society of Mining Engineers of the American Institute of Mining, Metallurgical and Petroleum Engineers: New York, NY, USA, 1985.

200. Valdivieso, A.L.; Escamilla, C.O.; Song, S.; Baez, I.L.; Martıxnez, I.G. Adsorption of isopropyl xanthate ions onto arsenopyrite and its effect on flotation. Int. J. Miner. Process. 2003, 69, 175-184. [CrossRef]

201. O'Brien, R.; Cannon, D.; Rowlands, W. Electroacoustic Determination of Particle Size and Zeta Potential. J. Colloid Interface Sci. 1995, 173, 406-418. [CrossRef]

202. Johnson, S.B.; Franks, G.; Scales, P.; Boger, D.V.; Healy, T.W. Surface chemistry-rheology relationships in concentrated mineral suspensions. Int. J. Miner. Process. 2000, 58, 267-304. [CrossRef]

203. Derjaguin, B.; Landau, L. Theory of the stability of strongly charged lyophobic sols and of the adhesion of strongly charged particles in solutions of electrolytes. Prog. Surf. Sci. 1993, 43, 30-59. [CrossRef] 
204. Verwey, E.J.W. Theory of the Stability of Lyophobic Colloids; Elsevier: Amsterdam, The Netherlands, 1948.

205. Diao, M.; Taran, E.; Mahler, S.; Nguyen, A. A concise review of nanoscopic aspects of bioleaching bacteria-mineral interactions. Adv. Colloid Interface Sci. 2014, 212, 45-63. [CrossRef] [PubMed]

206. Otsuki, A.; Hayagan, N.L. Zeta potential of inorganic fine particle-Na-bentonite binder mixture systems. Electrophoresis 2020, 41, 1405-1412. [CrossRef]

207. Elphick, K.; Yamaguchi, A.; Otsuki, A.; Hayagan, N.; Hirohata, A. Non-Destructive Imaging on Synthesised Nanoparticles. Materials 2021, 14, 613. [CrossRef] [PubMed]

208. Zhou, Y.; Han, Z.; He, C.; Feng, Q.; Wang, K.; Wang, Y.; Luo, N.; Dodbiba, G.; Wei, Y.; Otsuki, A.; et al. Long-Term Stability of Different Kinds of Gas Nanobubbles in Deionized and Salt Water. Materials 2021, 14, 1808. [CrossRef]

209. Israelachvili, J.N. Intermolecular and Surface Forces; Academic Press: London, UK, 2011.

210. Hogg, R.; Healy, T.W.; Fuerstenau, D.W. Mutual coagulation of colloidal dispersions. Trans. Faraday Soc. 1966, 62, $1638-1651$. [CrossRef]

211. Leong, Y.; Ong, B. Critical zeta potential and the Hamaker constant of oxides in water. Powder Technol. 2003, 134, 249-254. [CrossRef]

212. Flatt, R.J.; Bowen, P. Yodel: A Yield Stress Model for Suspensions. J. Am. Ceram. Soc. 2006, 89, 1244-1256. [CrossRef]

213. Otsuki, A. Coupling colloidal forces with yield stress of charged inorganic particle suspension: A review. Electrophoresis 2018, 39, 690-701. [CrossRef]

214. Genc, A.M.; Kilickaplan, I.; Laskowski, J.S. Effect of pulp rheology on flotation of nickel sulphide ore with fibrous gangue particles. Can. Met. Q. 2012, 51, 368-375. [CrossRef]

215. Bakker, C.; Meyer, C.; Deglon, D. Numerical modelling of non-Newtonian slurry in a mechanical flotation cell. Miner. Eng. 2009, 22, 944-950. [CrossRef]

216. Schubert, H. On the optimization of hydrodynamics in fine particle flotation. Miner. Eng. 2008, 21, 930-936. [CrossRef]

217. Li, C.; Cao, Y.; Peng, W.; Shi, F. On the correlation between froth stability and viscosity in flotation. Miner. Eng. 2020, 149, 106269. [CrossRef]

218. Wang, Y.; Peng, Y.; Nicholson, T.; Lauten, R.A. The different effects of bentonite and kaolin on copper flotation. Appl. Clay Sci. 2015, 114, 48-52. [CrossRef]

219. Farrokhpay, S.; Ndlovu, B.; Bradshaw, D. Behavior of talc and mica in copper ore flotation. Appl. Clay Sci. 2018, 160, $270-275$. [CrossRef]

220. Zhang, M.; Peng, Y.; Xu, N. The effect of sea water on copper and gold flotation in the presence of bentonite. Miner. Eng. 2015, 77, 93-98. [CrossRef]

221. Wang, Y.; Peng, Y.; Nicholson, T.; Lauten, R.A. The role of cations in copper flotation in the presence of bentonite. Miner. Eng. 2016, 96-97, 108-112. [CrossRef]

222. Xu, D.; Ametov, I.; Grano, S. Quantifying rheological and fine particle attachment contributions to coarse particle recovery in flotation. Miner. Eng. 2012, 39, 89-98. [CrossRef]

223. Zhang, M.; Peng, Y. Effect of clay minerals on pulp rheology and the flotation of copper and gold minerals. Miner. Eng. 2015, 70, 8-13. [CrossRef]

224. Basnayaka, L.; Subasinghe, N.; Albijanic, B. Influence of clays on the slurry rheology and flotation of a pyritic gold ore. Appl. Clay Sci. 2017, 136, 230-238. [CrossRef]

225. Schubert, H. On the turbulence-controlled microprocesses in flotation machines. Int. J. Miner. Process. 1999, 56, $257-276$. [CrossRef]

226. Li, C.; Runge, K.; Shi, F.; Farrokhpay, S. Effect of flotation conditions on froth rheology. Powder Technol. 2018, 340, 537-542. [CrossRef]

227. Li, C.; Runge, K.; Shi, F.; Farrokhpay, S. Effect of froth rheology on froth and flotation performance. Miner. Eng. 2018, 115, 4-12. [CrossRef]

228. Li, C.; Runge, K.; Shi, F.; Farrokhpay, S. Effect of flotation froth properties on froth rheology. Powder Technol. 2016, $294,55-65$. [CrossRef]

229. Liu, S.; Chen, X.; Lauten, R.A.; Peng, Y.; Liu, Q. Mitigating the negative effects of clay minerals on gold flotation by a lignosulfonatebased biopolymer. Miner. Eng. 2018, 126, 9-15. [CrossRef]

230. Cruz, N.; Peng, Y.; Wightman, E.; Xu, N. The interaction of clay minerals with gypsum and its effects on copper-gold flotation. Miner. Eng. 2015, 77, 121-130. [CrossRef] 